\title{
Voice and Action: \\ Sell-Side Analysis and Hedge Fund Activism
}

\author{
Huimin (Amy) Chen \\ Lally School of Management \\ Rensselaer Polytechnic Institute \\ chenh18@rpi.edu \\ Thomas D. Shohfi* \\ Lally School of Management \\ Rensselaer Polytechnic Institute \\ shohft@rpi.edu
}

November 2018

\begin{abstract}
Recent literature has shown hedge fund activism to be an important external corporate governance mechanism. Sell-side analysts, however, provide idea generation and analysis to buy-side clients including hedge funds. Using a propensity score matched sample, we examine sell-side analyst activity around hedge fund activism. We find that declining trends in analyst coverage begin in the year before hedge fund intervention and continue afterward. Stock market responses to analyst reports are negative before hedge fund intervention but revert to positive after. We introduce a new textual analysis dictionary to identify the activism objectives and tactics of Brav, Jiang, Partnoy, and Thomas (2008) within analyst reports and show pre-event sell-side reports contain significantly more language related to subsequent activism. Higher activism dictionary content in sell-side reports is correlated with activism-date target stock performance and predicts multiple activist interventions. Our results suggest that critical voice of sell-side analysis reveals coverage firm flaws that influence subsequent hedge fund intervention outcomes.
\end{abstract}

JEL Classification: G10, G20, G23, G29, M41

Keywords: Analysts; Buy-Side; Hedge Fund Activism; Hedge Funds; Sell-Side; Shareholder Activism

* Contact author.

We thank Bill Mayew, Gus De Franco, Shyam Kumar, James Potepa, Michael Weinz, and participants at the 2018 American Accounting Association Annual Meeting and 2018 Lally Research Symposium at Rensselaer Polytechnic Institute for helpful suggestions. We also thank the Donald Shohfi Financial Research Fund for computing support. 


\title{
Voice and Action: Sell-Side Analysis and Hedge Fund Activism
}

November 2018

\begin{abstract}
Recent literature has shown hedge fund activism to be an important external corporate governance mechanism. Sell-side analysts, however, provide idea generation and analysis to buy-side clients including hedge funds. Using a propensity score matched sample, we examine sell-side analyst activity around hedge fund activism. We find that declining trends in analyst coverage begin in the year before hedge fund intervention and continue afterward. Stock market responses to analyst reports are negative before hedge fund intervention but revert to positive after. We introduce a new textual analysis dictionary to identify the activism objectives and tactics of Brav, Jiang, Partnoy, and Thomas (2008) within analyst reports and show pre-event sell-side reports contain significantly more language related to subsequent activism. Higher activism dictionary content in sell-side reports is correlated with activism-date target stock performance and predicts multiple activist interventions. Our results suggest that critical voice of sell-side analysis reveals coverage firm flaws that influence subsequent hedge fund intervention outcomes.
\end{abstract}

JEL Classification: G10, G20, G23, G29, M41

Keywords: Analysts; Buy-Side; Hedge Fund Activism; Hedge Funds; Sell-Side; Shareholder Activism 


\section{Introduction}

Hedge fund activism has played an increasingly important role in capital markets over the last decade. For example, the number of hedge fund activists has almost doubled since 2001 (Brav, Jiang and Kim, 2015b) and total assets under their management rose about tenfold since 2003 to around $\$ 115$ billion in 2015 ( $\mathrm{PwC}, 2016)$. The rapid growth of hedge fund activism has substantial impact on public companies. According to former Security and Exchange Commission (SEC) Chairman Mary Jo White, hedge fund activists have "undeniably changed the corporate landscape" (White, 2015).

Prior literature focuses on hedge fund activism's impact on firm activities and stakeholders but overlooks how specific activism targets, objectives, or tactics are generated. Sell-side analysts may initiate research on firms and generate ideas that change firm fundamentals (Jung, Wong, and Zhang, 2014). Sell-side analysts also regularly share information, including investment ideas, research reports, estimates, and models, with buy-side institutions such as hedge funds. Brown, Call, Clement, and Sharp (2016) note that buy-side institutions are an important consumer of sellside research. It is therefore possible that activism target selection, objectives, or tactics conducted by hedge funds may be derived, at least in part, from sell-side analysis.

A case study of hedge fund Starboard Value and its targeting of Wasau Paper by Brav, Heaton, and Zandberg (2016) provides anecdotal evidence of the influence of sell-side analysts on subsequent activism. The authors show that a January 2014 letter by analyst Jeffrey Smith of hedge fund Starboard Value directly quotes a report by sell-side analyst Mark Wilde of Deutsche Bank which recommends asset disposition. The October 2012 sell-side report states "for nearly a decade, we've argued that Wasau ought to exit all paper operations and focus on its tissue business." A similar example is seen in Third Point Capital's targeting of Yahoo! in 2011. In a September 2011 
letter written to Yahoo!'s board of directors, Third Point's manager Daniel Loeb stated that “Yahoo's current stock price of $\$ 13.61$ per share - far below the Company's intrinsic value, which we current place in excess of $\$ 20$ per share." Just three months earlier, Piper Jaffray’s influential technology sell-side analyst Gene Munster wrote a report including a sum of the parts analysis of Yahoo! common stock with a value just above $\$ 20$ per share. $^{2}$

Given this anecdotal evidence, potentially generalized influence on hedge fund activists by sell-side research is an empirical question and a gap in the literature that we address. Firstly, we investigate whether the activities (reports, recommendations, etc.) of sell-side analysts change around hedge fund activism events. If sell-side analysts provide ideas for hedge funds, they may be more active before hedge fund interventions but gradually reduce activity as hedge funds take over. We begin by examining trends in analyst coverage between activist targeted firms and a control group formed through propensity score matching. We find declining trends in analyst coverage, including the number of estimates, recommendations, analysts following, analyst reports, and report length. The declining trends start the year before hedge fund intervention and continue after. This finding indicates a substitute relationship between sell-side analysts and hedge funds at monitoring firms. Sell-side analysts are more involved at following potential target firms before hedge fund interventions and gradually reduce their coverage as activists take over public scrutiny of the firm.

Secondly, we investigate whether the information provided by sell-side analysts before hedge fund intervention is valuable from investors' perspective. Buy-side institutions consume sell-side analysts' information through either private communication or public analyst reports. If sell-side analysts produce valuable research on potential target firms and publish such information

${ }^{1}$ Classic Dan Loeb: Read His Scathing Letter to the Yahoo Board, CNBC. https://www.cnbc.com/id/44441183

${ }^{2}$ Continue to Like YHOO in Black Half of 2011, Piper Jaffray, June 7, 2011. 
in analyst reports, ${ }^{3}$ investors may reflect the value of such information in their stock trading. We show that stock market responses to analyst research reports issued before activism are significantly negative. This finding indicates that investors value sell-side analyst reports, but, more importantly, it also implies that sell-side analysts reveal potential problems in target firms before hedge fund intervention.

Thirdly, we further explore the findings in analyst reports by textually analyzing the content of sell-side analyst reports and develop a new activist dictionary based on the objectives and tactics classifications of Brav, Jiang, Partnoy, and Thomas (2008). We find that reports from sell-side analysts on targeted firms exhibit significantly more language related to activism than control firms before hedge fund intervention and no significant difference than control firms after hedge fund intervention. This finding provides direct evidence that sell-side analysts generate activism ideas before hedge fund intervention. It also appears that sell-side analysts reduce their involvement in activism events after hedge fund intervention, consistent with our finding of reduced analyst coverage.

Finally, we take one step further to investigate whether activism-related content in sell-side reports is incorporated into hedge fund activism and affects intervention outcomes. We find significantly higher equity market responses to targets with more activism-related content in analyst reports produced up to nine months before intervention occurs. This implies that sell-side analysts' involvement in identifying and describing activism opportunities has a further effect on the incremental returns to hedge funds' intervention.

\footnotetext{
${ }^{3}$ Analyst reports are published by brokerage firms and accessible to their investors. Business journalists also publish quotes from analyst reports in news articles. See Five Things Investors Should Know About Analyst Reports. March 2016. http://www.finra.org/investors/five-things-investors-should-know-about-analyst-reports
} 
While sell-side analysts have a voice, they do not have the ability to threaten exit (Admati and Pfleiderer, 2009), launch a proxy fight, or conduct other activist tactics. Sell-side analysts provide idea generation for the buy-side institutions who possess these capabilities. With near constant presence (as opposed to transient institutional owners) and ongoing private communication with management (Brown, Call, Clement, and Sharp, 2015), sell-side analysts are more capable of revealing potential problems in coverage firms. When management no longer responds to sell-side opinions, which is reflected in decreased analyst coverage, hedge fund activism provides the "bite" that often compels management to respond.

Our work contributes to the literature by showing that sell-side analysts remain an important voice in external corporate governance through both directly scrutinizing management (Chen, Harford, and Lin, 2015) and indirectly by providing information and idea generation for activists. We note that our results are not consistent with prior work showing that the market acts less favorably to sell-side analysts who are under pressure by buy-side clients $(\mathrm{Gu}, \mathrm{Li}$, and Yang, 2012). While we cannot rule out that sell-side analysts provide a "negative marketing" function for hedge fund activists, our analyst report-level return results are robust to a geographical proxy for potential sell-side/hedge fund interaction. It is also less likely that this marketing function would begin nine months before 13D filing dates as our dictionary results show.

Our work also contributes to the literature of hedge fund activism by investigating the origins of activism ideas from sell-side analysts. Prior literature shows that activist hedge funds affect major changes in target firms and create value for shareholders (e.g. Brav et al. 2008, Brav et al. 2010; Brav et al. 2015a; Bebchuk et al. 2015; Brav et al. 2015b). Although activist hedge funds are the problem solvers of target firms and favored by shareholders, we show that sell-side analysts' negative voices reveal problems in target firms and facilitate hedge fund intervention 
outcomes. To our knowledge, we are the first paper to reveal sell-side analysts' negative voices and their contribution to activism success.

The remainder of the paper is organized as follows. Section 2 provides a literature review. Section 3 describes the data selection process and provides summary statistics. Section 4 presents the empirical results. We provide a brief conclusion in Section 5 .

\section{Literature Review}

\subsection{Analysts and Information Sharing}

To fulfill their role of information production in capital markets, sell-side analysts have a variety of job functions including generating earnings forecasts, constructing financial models, providing sale or purchase recommendations, writing research reports, and communicating with buy-side clients. This final responsibility is particularly important: through surveys of sell-side analysts, Brown, et al. (2015) show that client demand for information about a company is by far (very important to $72.33 \%$ of respondents) the most important determinant in sell-side coverage decisions.

Sell-side analysts' research may disseminate to buy-side clients through various channels, including public analyst reports and private communication channels. Mikhail, Walther, and Willis (2007) find that both large and small buy-side institutions respond to recommendation revisions within analyst reports. Certain buy-side institutions may receive privileged advanced access. Irvine, Lipson, and Puckett (2006) show that sell-side analysts privately communicate information to important investor clients before publishing reports. More specifically, Klein, Saunders, and Wong (2017) find that hedge funds are particularly likely to receive tips from sell-side analysts. On the other hand, Swem (2017) finds that hedge funds anticipate analyst reports, are faster than sell-side analysts, and that analysts assist them in using information in the marketplace. 
The transmission of information from sell-side analysts to buy-side institutions is particularly important to better understand the initial origins of hedge fund activism. We acknowledge that hedge funds also have buy-side analysts who issue research reports and provide ideas. However, sell-side analysts may play an important role in generating activism ideas for the following three reasons. First, sell-side analysts' promotions, job separations, and compensation are often determined by Institutional Investor (II) survey-based ranking, which is conducted by buy-side institutions such as hedge funds. Groysberg et al. (2011) shows that among a few factors that determine sell-side analysts' compensation, II "All-Star" status is the most important one in high-status investment banks. Given the importance of II ranking to career development, sell-side analysts have strong incentives to impress buy-side institutions. Second, with median (mean) hedge fund assets under management of \$29.1 (\$100) million (Agarwal, Daniel, and Naik, 2011), many funds are not large enough to enable its analysts to cover a larger proportion of public firms in depth and therefore rely on sell-side analysis to supplement and verify internal research. ${ }^{4}$ This is further confirmed by survey evidence of buy-side institutions by Brown, et al. (2016) showing that $72 \%$ of buy-side analysts follow more than 25 companies compared to just $9 \%$ for sell-side analysts. Lastly, prior literature shows that buy-side institutions may prefer sell-side analyst reports than buy-side analyst reports. For instance, Cheng, Liu, and Qian (2006) find that fund managers rely more on buy-side research only when buy-side analysis has higher information quality or when sell-side analysts are biased.

\footnotetext{
${ }^{4}$ Activist hedge funds are slightly larger than hedge funds in aggregate. Preqin tracks 793 activist hedge funds with $\$ 98$ billion under management in 2017 for mean AUM of \$123 million. See Should Investors be Wary of Activist Hedge Funds? July 2017. https://www.preqin.com/blog/0/18720/investors-wary-of-activist-hfs
} 


\subsection{Hedge Fund Activism}

\subsubsection{The Impact of Hedge Fund Activism}

In the last decade, hedge fund activism has exerted significant influence and imposed substantial changes on their target firms. Many studies have shown that hedge fund activism precipitates a positive stock market reaction. Brav et al. (2008) examines a sample of 1,059 hedge fund activism events over the period 2001-2006 and shows that abnormal returns to targets after announcement of activism are significantly positive. Following Brav et al. (2008), other papers have examined the stock market reaction using different samples or extending the test to long-term market performance (Clifford, 2008; Griffin and Xu, 2009; Klein and Zur, 2009; Brav et al., 2015a). These papers consistently find significant positive stock market returns.

Recent literature shows that the short-term positive stock market reaction is not temporary through activists" "pump and dump" schemes, in which activists reveal an under-valued stock to the market and sell for a short-term profit. Bebchuk et al. (2015) show that the short-term stock price jump of target firms does not reverse in the longer term. Hedge fund activists in fact create long-term value for target firms by effecting major changes to improve performance. The target firms underperform their peers at the time of intervention but their performance improves steadily in the following five years. Using plant-level information from the U.S. Census Bureau, Brav, Jiang, and Kim (2015a) find that a typical target firm improves production efficiency in the three years after intervention, especially following business strategy-oriented interventions. Despite a tightening in $R \& D$ expenditures, target firms experience an improvement in innovation efficiency during the five-year period following intervention (Brav, Jiang, Ma, and Tian, 2016). These studies consistently find that hedge fund activism makes real changes to create value for target firms. 


\subsubsection{Objectives and Tactics of Hedge Fund Activism}

Hedge fund activists have their own unique strengths at making significant improvements in their target firms. Hedge funds hire highly incentivized managers; they are not widely available to the public and are lightly regulated; they suffer few conflicts of interest with management of target firms and thus can act independently (Brav et al., 2008; Brav, Jiang and Kim, 2010)

With these strengths, hedge funds approach their target firms with publicly stated objectives. Prior literature (eg. Brav et al., 2008; Brav et al., 2015b; Greenwood and Schor, 2009) summarize the objectives into five categories: "general undervaluation/maximize shareholder value," "capital structure," "business strategy," "sale of target company," and "governance." The first objective is stated when hedge fund activists have no more specific goals or tactics other than communication with management. In the second category, the hedge fund intends to reduce excess cash, issue new debt, increase dividend payouts, launch stock repurchases, or call off seasoned equity offerings. In the third category, the stated objectives by hedge funds include general improvement of operational efficiency, cost cutting, tax efficiency enhancing, spinning off noncore assets, refocusing business strategy, and intervening mergers and acquisition. The fourth objective includes selling company or main assets to a third party, or taking control of the target company. The fifth category - governance improvement manifests in rescinding takeover defenses, ousting the CEO, chairman/board independence and fair representation, more information disclosure to identify potential fraud, and eliminating excess executive compensation for substandard performance.

In this regard, hedge fund activists use various tactics to effectively fulfill their objectives.

Ranging from the least to the most aggressive approaches, these tactics include frequent communication with the board or the management, board representation, confrontation with management or the board, formal shareholder proposals, a proxy fight or proxy contest, lawsuits, 
and takeover bids. In addition, hedge funds may work together as a "wolf pack" by following each other's target firms. Becht et al. (2017) find that interventions involving multiple activists show significantly higher target returns. These powerful tactics are hedge fund activists' unique features and facilitate their intended changes imposed on target firms.

\subsection{Sell-side Analysis and Hedge Fund Activism}

It appears that hedge fund activists have effective tactics to execute their objectives and successfully improve firm performance. Nonetheless, one question that has been overlooked in the extant literature is how hedge funds detect problems, define objectives, and choose tactics for their target firms. This paper fills in this literature gap by examining the potential role of sell-side analysis.

Unlike hedge funds, sell-side analysts do not possess capabilities to influence target firms and thus may have less involvement after hedge fund intervention. About one-fourth of hedge fund intervention events are resisted by target firms via poison pills, lawsuits, and restrictions on shareholder actions (Boyson and Pichler, 2016). Hedge funds can counter this resistance through various powerful tactics that sell-side analysts cannot execute. While hedge funds are action takers, sell-side analysts may use their voices and be active before hedge fund intervention.

We further argue that sell-side analysts may reveal problems in potential target firms before hedge fund activists' intervention. Sell-side analysts produce large amount of valuable information through extensive research. Affiliating with buy-side institutions in many ways, sell-side analysts may share information and form common ideas. Brav et al. (2008) find that during the 12 months before activism is announced, stock downgrades outnumber upgrades, but significantly decrease during the event month and the two subsequent months. It appears that sell-side analysts recognize 
problems in potential target firms before hedge fund intervention, but adjust their views after hedge fund intervention. If sell-side analysts voice their opinions of target firms before hedge funds' intervention actions, investors may value such voice and reflect in their stock trading.

More specifically, the content in analyst reports before hedge fund intervention may give direction to hedge funds by identifying possible objectives or even choosing potential tactics. The most valuable information in analyst reports reveals problems in coverage firms, leading to downgrades (Asquith, Mikhail, and Au 2005). Although sell-side analysts have critical voices in the content of their reports and trends in recommendations, their information may contribute to the subsequent success of hedge fund intervention.

Based on the discussion above, we make the following predictions. First, sell-side analysts are more active before hedge funds intervention and decrease their involvement thereafter. Second, analyst reports reveal valuable information to investors, although we cannot predict whether investors react positively or negatively to this information. If investors recognize problems revealed by sell-side analysts, firm common stock may react negatively; if analysts imply any intention or plans by firm management of solving problems and improving performance, the stock market may react positively to pre-intervention reports. Third, analyst reports consist of information content related to and preceding hedge fund activism and this content influences subsequent intervention outcomes, particularly activism announcement date target equity returns. Further, if more activism-related, pre-intervention sell-side report content stimulates hedge fund interest in target firms, we are more likely to observe subsequent activism involving multiple hedge funds. 


\section{Data}

We use a unique dataset of hedge fund activism events to test our research question. Following Brav et al. (2008), we start our data collection process by gathering the entire set of Schedule 13D filings from the SEC's EDGAR database between 2008 and 2017. Using the information contained in item 2 of Schedule 13D, we then exclude filers that are classified as banks, brokerage companies, regular corporations, foreign institutions, individuals, insurance companies, pension funds, and trusts. After cross-checking with the activist hedge funds contained in Brav et al. (2008), ${ }^{5}$ we use Google search to pin down a list of activist hedge funds from the remaining filers. We then exclude those Schedule 13D filings that are related to risk arbitrage, distressfinancing, and M\&As, or those targeted by investment trusts or closed-end funds. The remaining Schedule 13Ds filed by the list of activist hedge funds represent all the activist events where more than $5 \%$ of the target company's shares are owned by the activist hedge funds. For hedge fund activism events that are not contained in Schedule 13D (fewer than 5\% of the target company's shares), we follow the procedures in Brav et al. (2008) to obtain information.

Starting with 4,669 hedge fund activist target events during the sample period, we only include the first-time target event for each firm and require at least one-year of accounting data before and after the event. This procedure yields 1,800 targeting events. The purpose of this data selection is to carry out propensity score matching, ${ }^{6}$ which is based on annual accounting information. We merge the remaining events with Compustat data for accounting information and with other datasets for matching criteria such as institutional ownership. Before propensity score matching, we have 1,286 events. The matching process is summarized in section 4.1 and in Table

\footnotetext{
${ }^{5}$ We thank Wei Jiang for kindly sharing the activism events used in Brav at al. (2008). Please refer to the paper for a more detailed description.

${ }^{6}$ The propensity score matching procedure substantially reduces the amount of manual data collection required from several datasets (e.g. Investext, Capital IQ) but still produces robust analytical results.
} 
2. In total 876 events are matched with the control group based on the propensity score matching model in Brav et al. (2008). The detailed data selection process is presented in Panel A of Table 1.

\section{[Insert Table 1 here]}

Using the propensity score matched sample as the starting point, we collect several datasets that indicate analyst activities, including earnings estimates and recommendations, earnings conference calls, and analyst reports. First, we merge the propensity score matched sample with I/B/E/S for EPS estimates and recommendations. Second, we manually collect transcripts of earnings conference calls from S\&P Capital IQ. Sell-side analysts actively participate in conference calls and interact with senior management. Third, we manually collect analyst reports from the Investext database. Analysts reports give detailed information about analyst views and ideas about the firm. The issuance of analyst reports also releases important information to capital markets. Last, we merge the datasets with CRSP and Compustat for stock price and accounting information.

\section{Empirical Results}

\subsection{Summary Statistics and Propensity Score Matching}

\subsubsection{Summary Statistics}

After constructing the datasets, we provide summary statistics in Panel B of Table 1 for all variables used in the empirical tests. The sample includes both the treatment group and the control group. All continuous variables are winsorized at the top and bottom 1\%. Detailed descriptions of all variables are provided in Appendix A.

NUMEST is the number of earnings estimates and NUMREC is the number of recommendations, both of which are from the I/B/E/S database. The average number of estimates is 5.068, while the average number of recommendations is 6.975. NUM_ANALYST is the number 
of analysts (including sell-side, buy-side, and independent analysts) participating on earnings conference calls. ${ }^{7} N U M \_S E L L S I D E$ is the number of sell-side analysts who participate on individual firm earnings conference calls. On average, around four sell-side analysts participate earnings conference calls, while around five analysts of all types participate conference calls. The high participation rate of sell-side analysts is consistent with prior studies (e.g., Call, Sharp, and Shohfi, 2018). The average numbers of earnings estimates and recommendations are slightly higher than the average number of total analysts who participate on earnings conference calls, implying that majority of sell-side analysts participate on earnings conference calls of firms in our sample. NUM_REPORT is the aggregate number of analyst reports issued each month for a given firm with $N U M_{-} P A G E$ (NUM_WORD) as the number of pages (words, in thousands) in each report. On average approximately seven reports are issued on a firm each month.

The summary statistics of firm characteristic variables are comparable with prior studies. $R O A$, which is net income divided by total assets, has an average of $-3.2 \%$ in our sample. This negative value is primarily because our sample covers firms during and post the financial crisis when the profitability of many firms, particularly those targeted for turnaround by activists, is negative. Median ROA is $2.3 \%$, which is more comparable to prior literature. SIZE is the natural logarithm of total assets. BTM is measured as the book value of common stock divided by the market value. MISS is an indicator variable that equals one if the actual earnings per share (EPS) is less than the last consensus forecast, and zero otherwise. We include this variable to control for the effect of missing earnings targets. On average 17.6\% of announced earnings miss analysts' expectations, which is comparable to recent literature (e.g., Huang, Lehavy, Zang and Zheng,

\footnotetext{
${ }^{7}$ Additional DID tests on Loughran and McDonald (2011) sentiment measures (positive, negative, net tone, and uncertainty) within earnings conference calls (and separate analysis for Q\&A) for treatment and control groups are provided in Appendix II of the internet appendix.
} 
2017). $T P / P$ is the ratio of target price divided by actual price. The mean of $T P / P$ is 2.285 , which is abnormally high. However, the high average $T P / P$ is reasonable in the context of hedge fund activism target firms - these firms tend to be undervalued; the high $T P / P$ is also driven by the data of the post financial crisis period, when some firms are recovering and expected to have significant increases in stock prices. The median of $T P / P$ is 1.215 , comparable to prior studies (e.g., Brav and Lehavy, 2003). EST/ACT is estimated earnings divided by actual earnings and has average of $0.966 .^{8}$

\subsubsection{Propensity Score Matching}

We use propensity score matching to prepare a dataset for manual collection of earnings conference calls and analyst reports, both of which demonstrate sell-side analysts' participation in researching companies. Before matching, we identify the initial pool of candidate match firms as public firms that have not been targeted by hedge fund activists during our sample period. In total 39,308 firm-year observations are in the pool. We follow recent studies (e.g., Brav et al., 2008) and use propensity score matching to identify one matched firm for each treatment firm. These two groups of firms ideally have the same firm characteristics except that one group of firms has been targeted by hedge fund activists and the other group of firms has not. We identify a nontarget control firm with the closest propensity score in event year $\mathrm{t}-1$.

Following Brav et al. (2008), we use a probit model to estimate the probability of being targeted by hedge fund activists to obtain a propensity score. The model is:

$$
\begin{aligned}
D_{-} \text {TARGET }_{i, t} & =\beta_{0}+\beta_{1} \text { MV }_{i, t-1}+\beta_{2} Q_{i, t-1}+\beta_{3} G_{R O W T H_{i, t-1}}+\beta_{4} \text { ROA }_{i, t-1} \\
& +\beta_{5} L E V_{i, t-1}+\beta_{6} \text { DIVYLD }_{i, t-1}+\beta_{7} R N D_{i, t-1}+\beta_{8} H H I_{i, t-1} \\
& +\beta_{9} \text { ANALYST }_{i, t-1}+\beta_{10} I N S T_{i, t-1}+\epsilon_{i, t}
\end{aligned}
$$

\footnotetext{
${ }^{8}$ Additional DID tests on TP/P and EST/ACT for treatment and control groups are provided in Appendix I of the internet appendix.
} 
D_TARGET equals one if the firm is a hedge fund activism target in year $\mathrm{t}$ and zero otherwise. Brav et al. (2008) have identified certain characteristics of target firms. They tend to be undervalued, low growth, but highly profitable. $M V$ is the $\log$ of market capitalization. $Q$ is Tobin's Q. GROWTH is the growth rate of sales over the previous year. Regarding capital structure, target firms tend to have lower dividend payouts and high leverage. DIVYLD is the dividend per share. $R N D$ is $\mathrm{R} \& \mathrm{D}$ scaled by total asset. Target firms are more diversified. $H H I$ is the HerfindahlHirschman index of sales in different business segments as reported by COMPUSTAT. Targets also have significantly higher institutional ownership and analyst coverage. ANALYST is the number of sell-side analysts covering the firm. Firms without analysts following are indicated as zero for the variable ANALYST. ${ }^{9}$ INST is the level of institutional ownership. For a detailed description of variables, refer to Appendix A.

The result of the probit model is presented in Panel A, Table 2. The results are mostly consistent with Brav et al. (2008). Target firms tend to be low growth firms, but are significantly more profitable. The variables for growth such as $Q$ and GROWTH have negative coefficients. The variable for profitability, $R O A$, has positive coefficient. The negative coefficient on DIVYLD indicates that target firms' dividend payout is relatively lower than peer firms. They are also relatively more diversified (coefficient of $\mathrm{HHI}$ is -1.080 , significant at $1 \%$ level). Target firms tend to have higher institutional ownership. In our regression model, the sign of ANALYST is positive (coefficient 0.012 , t-stat 5.876). In the extant literature, it is unclear which direction of this coefficient should be expected. Brav et al. (2015b) points out possible multicollinearity problems between INST and ANALYST. In this paper, we do not investigate the cross-sectional variation of

\footnotetext{
${ }^{9}$ About $40 \%$ of observations in model (1) of Table 2 have zero analyst following.
} 
analyst coverage among firms but focus on analysts' role before and after hedge fund intervention. Therefore, the sign and possible multicollinearity problem are not concerns of this paper. The interpretations of these variables are all consistent with the findings in the prior literature.

[Insert Table 2 here]

In the next step, we obtain the predicted value of the probit model as the propensity score. Without replacement, we match each hedge fund target firm with a control firm that has the closest propensity score in the same year. Firms that are matched in prior years will be excluded from the pool of candidate matched firms. To ensure that there are no significant differences between treatment firms and matched firms, following Brav et al. (2008), we use the caliper matching method, in which caliper refers to the difference in the predicted probabilities between treatment and matched firms. By matching within a caliper of 3\%, we are able to identify 876 treatmentmatch pairs from this propensity score matching method.

We compare the statistics of the treatment and matched firms. The comparison is presented in Panel B, Table 2. For all but two of the variables, the t-statistics for the mean difference between treatment firms and match firms are not significant. This means that our matching method gives balanced treatment and matched samples. After matching, we expand the sample to include the proceeding and succeeding firm-year observations for each treatment and matched firm.

\subsection{Changes in Analyst Coverage after Hedge Fund Intervention}

\subsubsection{Trend Visualization}

In this section, we test whether analyst activity changes around hedge fund intervention. First, we plot the number of estimates and the number of recommendations, both of which have large datasets available from I/B/E/S, from 12 months before through 12 months after hedge fund intervention. We also display trend lines for each time series. The graphs are in Figure 1. The 
monthly average number of estimates for the treatment group decreases gradually over time, while the monthly average number of estimates for the control group stays about the same level. The declining trend starts before hedge fund intervention.

\section{[Insert Figure 1 here]}

Second, we plot the number of analyst reports from 12 months before through 12 months after hedge fund intervention. The graph is in the first row of Figure 2. The number of analyst reports cluster within three months before and after hedge fund intervention and show clear decline within three months after intervention. Although the overall pattern is not very clear throughout 12 months before and after intervention, we see a downward trend line of monthly average number of analyst reports and report length for the treatment group, while a relatively flat trend line for the control group.

\section{[Insert Figure 2 here]}

Last, we plot the number of analysts participating in earnings conference calls through 12 months before and 12 months after hedge fund intervention. The graph is in the second row of Figure 2. The pattern is similar to Figure 1 . We can see that the monthly average number of sellside analysts participating in conference calls for the treatment group decreases gradually over time, while for the control group it stays about the same level.

\subsubsection{Univariate DID Test}

We continue our analysis with univariate DID test using several datasets that capture analyst coverage: I/B/E/S, earnings conference calls, and analyst reports. We use t-tests on the difference between the treatment and control groups (propensity score matched firms) as well as the difference between pre-targeting and post-targeting periods. The results are in Panel A of Table

3. For a detailed description of these variables, refer to Appendix A. For the full-sample summary 
statistics of the variables, refer to Table 2. In the treatment group, most variables show a significant reduction after targeting events. For example, compared to the pre-targeting period, NUM_SELLSIDE during the post-targeting period is 0.308 lower (t-stat -2.85 ), significantly at the 5\% level. This means that sell-side analyst activity has significantly reduced after hedge fund intervention. The only variable that has a different result is $N U M_{-} P A G E$, which has a positive, but insignificant, mean difference of 0.031 ( $\mathrm{t}$ stat 0.62 ).

\section{[Insert Table 3 here]}

In the univariate DID test, all variables have negative estimators, which indicates a reduction in analyst coverage. For example, the DID estimator for NUM_SELLSIDE is -0.344 (tstat -2.23), significant at the $1 \%$ level. This means that, compared with control group, the treatment group has a significantly higher reduction in sell-side analyst activity. The DID estimators and t-

stats for other variables, except NUMREC are consistent. This provides strong evidence that analyst coverage has significantly reduced after hedge fund intervention. The decline in analyst coverage may be due to management intentionally ignoring the calls to improve governance and/or shareholder value in specific ways by analysts. These analyst voices ("bark") are later put into action by hedge fund activists ("bite"). We explore this possibility later in Section 4.4 through pre-targeting content analysis of sell-side analyst reports.

\subsubsection{Multivariate DID Regression}

The findings in the univariate DID test may be driven by other correlated factors. In this section, we use multivariate DID regression models and include control variables. The dependent variables are the same as the univariate test: NUMEST, NUMREC, NUM_ANALYST, NUM_SELLSIDE, NUM_REPORT, NUM_PAGE, and NUM_WORD. We create new variables to indicate the assignment and timing of treatment. TREAT is an indicator variable that takes the value 
of one if the firm has been targeted during the sample period (treatment group), and zero otherwise (control group). POST is an indicator variable that takes the value of one if year $\mathrm{t}$ is after a firm has been targeted by hedge fund activists, and zero otherwise. Our variable of interest is the interaction term $T R E A T^{*} P O S T$. In the regression model, we also include relevant control variables and firm fixed effects. These firm characteristics may impact the amount of analysis required and analyst interests (Lang and Lundholm, 1993).

The results are in Panel B of Table 3. Our variable of interest TREAT*POST is consistently negative in all of regression models. For example, in column (1), the coefficient is -0.367 (t-stat 3.737), significant at the $1 \%$ level. This means that compared with matched firms, target firms have even greater decreases in sell-side analyst participation during conference calls. The results are similar for the total number of analysts, number of analyst reports, number of estimates or recommendations. These findings indicate that, compared with matched firms, target firms have significant reduction in analyst activities, including participating in conference calls, releasing research reports, issuing earnings estimates, and providing stock recommendations. These results support our prediction that analysts' roles change after hedge fund intervention. It is possible that, with a variety of more effective tactics at their disposal, hedge funds act as a substitute for sellside analysts at monitoring target firms.

\subsection{The Value of Analyst Reports to Investors}

In this section, we further investigate the value of sell-side analysis in the context of hedge fund activism. Prior literature has shown that sell-side written reports are informative to capital markets (Mikhail, Walther, and Willis 1999; Asquith et al. 2005; Kadan, Madureira, Wang, and Zach 2012). Sell-side analysis may contain information related to subsequent activist intervention opportunities. We conduct an event study of analyst reports before hedge fund intervention to 
examine whether and how the information is valuable to investors. Moreover, we compare the stock market reaction to analyst reports issued before and after hedge fund interventions.

The extant hedge fund activism literature shows that investors react favorably in response to hedge fund activist intervention events. For example, Brav et al. (2008) shows that target firms' abnormal returns from 20 days before to 20 days after the announcement of activism are significantly positive. These intervention events give a strong signal to the market that hedge funds will actively attempt to solve existing problems and improve firm performance. Sell-side analysts may reveal problems of target firms in their analyst reports before hedge funds intervene, but we do not know how the stock market reacts to issuance of these reports. If investors value this information, firm common stock may react negatively to the problems revealed; if analysts imply any intention or plans of solving problems and improving firm performance, the stock market may react positively to pre-intervention reports.

To test the stock market reaction to sell-side analyst reports, we select analyst reports that are issued within 90 days to 5 days prior to hedge fund activist intervention events. We perform an event study on these analyst reports. To mitigate confounding effects, we exclude reports issued five days before or after targeting event dates and limit testing windows of CAR within five days. To mitigate confounding effects from other possible information released concurrently to the stock market, we perform an event study on our propensity-score matched firms as well. For each firm that is matched with a target firm, we use the intervention event date of the target firm for the matched firm as the artificial intervention date. Any analyst reports issued within 90 days and 5 days prior to the artificial intervention date are included into the sample for the event study. The results of these two event studies are shown in Panel A of Table 4.

[Insert Table 4 here] 
We select multiple event windows around the issuance dates of analyst reports and test cumulative abnormal returns (CARs) using the market model. For the treatment group (firms that are later targeted by hedge funds), in each of the event windows, CARs are negative and significant at the $1 \%$ level. For example, in Panel A of Table 4, target firm cumulative abnormal returns from 5 (2) days before to 5 (2) days after the issuance of analyst reports are $-1.04 \%(-1.38 \%)$, (Patell z stat $-4.45(-7.64))$, significant at the $1 \%$ level. Moreover, the event study for the control group does not have significant results on CAR. In Panel A in Table 4, matched firm CARs for all event windows are not statistically significant. Overall, these results show that the stock market does not significantly react to analyst reports issued for the firms in our control group. Comparing the results of the control group with the treatment group, we can see that investors react negatively to analyst reports within the quarter before activist hedge funds' intervention.

We take our analysis one step further by comparing market reaction to analyst reports before and after hedge fund intervention by conducting univariate difference-in-difference tests. Before hedge fund intervention, treatment group (target) firms have significantly higher CARs than control group (matched) firms. For example, mean CAR of event window $(-1,+1)$ for the treatment group $-1.33 \%$ is lower than $-0.32 \%$ for the control group ( $\mathrm{t}$ stat -6.15$)$, a difference that is significant at the $1 \%$ level. This finding is similar for other event windows. After targeting, the difference between treatment and control group firms is not statistically significantly. For example, mean CAR of event window $(-1,+1)$ for treatment group firms is $0.73 \%$, which is lower than $0.79 \%$ for the control group (t stat -0.48), but not significantly different. Lastly, we test difference in differences and find that, compared to control group, the increase in CARs after targeting for the treatment group is significantly higher. For example, the DID estimator for the event window (-1, +1 ) is $0.94 \%$ and has a t statistic of 4.34 , significant at the $1 \%$ level. 
In Panel B, we also run regressions to control for factors that can explain the stock market performance. It is possible that target firms underperform before hedge fund interventions and have negative stock returns. To mitigate this concern, we include relevant control variables including ROA, LNMV, LTDEBT, BTM, and MISS. We also control for research analyst brokerage fixed effects. The dependent variable is CARs in the window of $[-1,+1]$ around issuance of analyst reports. In column (1), we include only analyst reports issued within 5 to 90 days before activism events. We use the variable TREAT as our variable of interest to indicate whether a firm is in treatment group or control group. The coefficient of TREAT is -0.008 ( $\mathrm{t}$ stat -2.950$)$, significant at the 5\% level. It means that the treatment firms have significantly lower CARs around issuance of analyst reports than the control group. In column (1), we include analyst reports issued within 5 to 90 days before or after activism events. We use the interaction variable TREAT*POST as our variable of interest to test whether stock returns revert from negative to positive. The coefficient on TREAT*POST is 0.009 (t stat 2.344), significant at the 5\% level. It means that the treatment firms have significantly higher CARs after activism events than the control group, supporting our DID estimator in Panel A. These findings indicate that our event study results are not driven by firm fundamentals but imply the value of information revealed by analysts.

To sum up, all of the findings indicate that sell-side analysts reveal valuable information through reports before hedge fund intervention. The negative stock market reaction implies that analysts reveal negative information, likely identifying problems in potential target firms. This release of negative information occurs before hedge funds intervene. The positive stock market reaction to analyst reports after hedge fund intervention implies that investors recognize the problem-solving capabilities of activist hedge funds. 


\subsection{Activism Dictionary in Analyst Reports}

Given the findings above, we specifically investigate whether sell-side ideas within analyst reports align with hedge fund activist interventions. We start with the categorization of objectives in Brav et al. (2008) and develop a custom activist dictionary. We identify keywords and synonyms for each specific objective and tactic. The complete dictionary is provided in Appendix B.

We perform textual analysis on analyst reports by counting the number of words that match with our dictionary. We scale the number of dictionary words by the total number of words in analyst reports for a percentage of dictionary words. We plot the time series of the percentage of activist dictionary words relative to total words in analyst reports (first row) and earnings conference call Q\&A (second row) in Figure 3. Relative to the increasing control group, activist dictionary content is declining over time in analyst reports and conference calls. These figures provide preliminary evidence that sell-side analysts provide more activism specific information before hedge fund intervention.

\section{[Insert Figure 3 here]}

We next perform univariate DID test on the percentage of dictionary words. The results are in Table 5. We find that before hedge fund intervention, the activism dictionary percentage in analyst reports of the treatment group is significantly higher than that in control group. We compare analyst reports during different time periods. For example, DIC (one month) includes analyst reports issued for treatment group (or control group) within one month before (or after) hedge fund intervention, while DIC (two month) includes analyst reports issued for treatment group (or control group) within two months before (or after) hedge fund intervention. Our univariate t-test shows that before hedge fund intervention, DIC (one month) for the treatment 
group is $0.342 \%$ higher than the control group ( $\mathrm{t}$ stat 2.66), significant at the 5\% level. This finding is similar for other event windows. ${ }^{10}$

\section{[Insert Table 5 here]}

Next, we find that compared to control group, the reduction in activism dictionary words for the treatment group is significantly higher than for the control group. For example, the DID estimator for DIC (one month) is $-0.466 \%$ (t stat -2.49 ), significant at the $5 \%$ level. This means that, compared with the control group, the decrease of activism dictionary percentage in analyst reports from one month before intervention event to one month after is significantly higher for the treatment group.

These findings show that sell-side analysts generate ideas that are in-line with activist hedge fund objectives and tactics. It also shows that sell-side analyst idea generation occurs before hedge fund intervention. After hedge fund intervention, sell-side analysts significantly reduce activism related content in analyst reports. It appears that activist hedge funds take over from sellside analysts. These findings further support our prediction that sell-side analysts provide specific objectives and suggestions to hedge funds regarding activism.

\subsection{The Effect of Activism Dictionary on Hedge Fund Intervention Events}

In this section, we investigate whether activism dictionary content in pre-event analyst reports has any effect on hedge fund intervention event returns. Although we have shown that activism-related content appears in analyst reports before intervention events, we still do not know whether hedge funds incorporate this report content in their actions of activism events. In other

\footnotetext{
${ }^{10}$ Our sample for this test does not include firms that do not have analyst reports. Therefore, we also run a more conservative test including these firms in the sample. The results are very similar and are available in Appendix III of the internet appendix.
} 
words, we do not know whether the appearance of the content has further impact on the stock market reaction to intervention events. We investigate this question by testing the relationship between the activism dictionary and CARs of activism events. We run our tests on target firms (treatment group) only in this section.

To confirm investors' positive reaction to hedge fund intervention, we perform an event study on hedge fund intervention events and have findings consistent with Brav et al. (2008). For example, mean CAR of event window $(-20,20)$ is $4.60 \%$ in their paper, while $4.68 \%$ in ours. Next, we sort the activism dictionary percentage in 3-month pre-intervention analyst reports and group them into two subsamples. One subsample "High Dictionary Content" includes reports with activism dictionary percentage above the median of $4.843 \%$ in 3 -month pre-intervention reports; the other subsample includes reports with activism dictionary percentage below the mean. We conduct a univariate test of the difference in activist intervention date CARs between these two subsamples. The results are in Panel A of Table 6.

\section{[Insert Table 6 here]}

First, we find that the firms with high dictionary pre-event analyst report content have significantly higher CARs around intervention events. For example, CARs of intervention event window $[-1,+1]$ for high dictionary coverage subsample is $4.032 \%$, which is higher than $3.341 \%$ for low dictionary coverage subsample (t stat 6.11), is significant at the $1 \%$ level. The results are similar for CARs of other event windows. ${ }^{11}$

\footnotetext{
${ }^{11}$ The average mean CARs of window $[-20,+20]$ for analyst reports $(5.929 \%+4.697 \%) / 2=5.313 \%$ is higher than $4.843 \%$ for all intervention events. The slightly higher return is because some intervention events do not have analyst reports.
} 
Second, to control for other factors correlated with dictionary coverage, we run OLS regression of CARs on dictionary coverage percentage. ${ }^{12}$ We use CARs of window $[-1,+1]$ as the dependent variable. Our variable of interest is $D I C \_H I G H$, which is an indicator variable that takes the value of one if monthly dictionary coverage is above median of the sample, and zero otherwise. We run regressions using different cut-off points of analyst reports. For example, model (1) includes analyst reports issued nine months before hedge fund intervention; model (2) includes analyst reports issued six months before hedge fund intervention. We also include brokerage firm fixed effects.

We follow the model (Table V) in Brav et al. (2008) and include ROA, LNMV, LTDEBT (long-term debt ratio), BTM (book-to-market), and MISS as control variables. LNMV is the natural logarithm of market capitalization; MISS is an indicator variable that equals one if the actual EPS is less than the last consensus EPS forecast, and zero otherwise. The results are in Panel B of Table 6.

In model (2), our variable of interest DIC_HIGH has a coefficient of 0.009 (t stat 1.719), significant at the $10 \%$ level. This means that high activism dictionary percentage in 6-month preevent analyst reports leads to $0.9 \%$ higher in CARs of activism events. We find similar results in model (3), which includes analyst reports issued 3 months before activism events.

Next, to further demonstrate the influence of sell-side analysis on subsequent activism we examine the determinants of interventions involving multiple activists. Consistent with Becht et al. (2017), we find that $22.4 \%$ of our intervention identifiers involve multiple activists. If sell-side

\footnotetext{
${ }^{12}$ Since Becht et al. (2017) find that returns involving multiple activists are significantly higher than interventions by a single hedge fund, we rerun our multivariate CAR analysis to include a MULTIACTIV indicator variable and report this qualitatively similar results in Appendix IV of the internet appendix.
} 
analysts stimulate interest in activist ideas of their coverage firms, then more activism-related content should be associated with a greater probability of multi-activist intervention. Logit regression results in Table 7 are consistent with this prediction. The coefficient of DIC_HIGH is positive and statistically significant at the $1 \%$ level in each specification. Above median activism dictionary sell-side report content six (three) months before intervention is associated with a $28.8 \%$ (14.4\%) increase in the probability of multi-activist involvement.

\section{[Insert Table 7 here]}

These findings show that the activism-related ideas generated by sell-side analysts have a further economically significant impact on the returns of activism events. Increased probability of multiple-activist intervention when sell-side report activism dictionary content is higher suggests that analysts promote potential targets. It appears that activist hedge funds incorporate sell-side analysts' ideas into their actions, which are valued by investors.

\subsection{Robustness Tests}

\subsubsection{Test of Communication between Sell-side Analysts and Hedge Funds}

Our findings above indicate that analysts have influence on hedge fund interventions, but do not give direct evidence of communication between analysts and hedge funds. To address this concern, we use the geographical distance between analysts' brokerage firm headquarters and activist hedge funds' headquarters to proxy for the intensity of communication.

Firstly, analysts and hedge funds that are close to each other geographically should have more communication and are more likely to share ideas. We use the distance between analyst brokerage and hedge fund office zip codes from Capital IQ to measure geographical distance. ${ }^{13}$ In

\footnotetext{
${ }^{13}$ We use "ZIPCITYDISTANCE" command in SAS to calculate numeric distance between zip codes.
} 
Table 8 (both Panel A and Panel B), we divide the sample into two groups based on the geographical distance between hedge funds and brokerage firms. Short Distance consists of sample below-median distance; while Long Distance consists of sample above-median distance. As an example, for analyst reports issued within three months to five days before targeting, the median geographical distance between brokerage firms of sell-side analysts and hedge funds headquarters is 289.8 miles. We include any analyst reports with distance below 289.8 in the subsample of "Short Distance" and those above in "Long Distance". We divide the sample using different median distance in different periods of analyst reports. We compare the dictionary words percentage in these two subsamples and run t-test on the difference. For example, for analyst reports issued within three months to five days before targeting, we find that analyst reports in the short-distance subsample has significantly less dictionary content than the long-distance subsample (mean difference $-0.568 \%, \mathrm{t}$ stat -3.91 ). The $\mathrm{t}$-tests of other periods of analyst reports provide similar results. These findings indicate that sell-side analysts disclose less activism-related content in their reports if they are close to hedge funds and thus may use other communication channels to deliver ideas.

\section{[Insert Table 8 here]}

Secondly, we test whether investors value information in analyst reports differently based on geographical distance. We divide the sample into "Short Distance" and "Long Distance" using the sample median of analyst reports issued within three months before and after targeting. We use similar model specification in column (2) of Table 4 Panel B. Since we test only on treatment firms, our variable of interest is POST, which is an indicator variable that takes the value of one if year $\mathrm{t}$ is after a firm being targeted by hedge fund activists, and zero otherwise. In each subsample, POST 
is positively significant at the $1 \%$ level, meaning that investors do not value analyst reports differently based on geographical distance.

Lastly, we also perform similar analysis in section 4.2 .3 by geographical distance. ${ }^{14} \mathrm{We}$ find that in the subsample of short distance, $N U M_{-} P A G E$ and $N U M_{-} W O R D$ for treatment firms significantly reduce after intervention events, while in the subsample of long distance, NUM_PAGE and NUM_WORD for treatment firms do not significantly change. This finding further supports our conjecture that sell-side analysts communicate their ideas with hedge funds and reduce the length of their analyst reports more than those with long distances from hedge funds.

\subsubsection{Alternative Test Windows and Model Specifications for Event Study}

In section 4.3, one potential criticism is our cut-off points of analyst reports. Alternatively, we select analyst reports 15 days, 30 days, or 60 days prior to hedge fund intervention and perform an event study on these analyst reports. We exclude analyst reports issued 5 days prior to intervention in these event studies because the market reaction may be confounded by activism events that occur only a few days later. We continue to find negative stock market reaction to analyst reports of target firms and no significant reaction to matched firms. We also test the validity of our event study results by using alternative model specification: adjusted market returns and Fama-French model with momentum factor, calculated with either value-weighted or equallyweighted indices. The results are similar. ${ }^{15}$

\subsubsection{Other Tests}

For our findings of reduction in analyst coverage (Table 3 Panel B), we control for brokerage firm fixed effects for the tests of analyst reports. One can argue that the decrease in the

\footnotetext{
14 The results are very similar and are available in Appendix V of the internet appendix.

15 The results are available in Appendix VI of the internet appendix.
} 
number of analyst reports and report length is due to certain brokerage firm effects. We still have similar findings for column (5), (6), and (7) after including brokerage firm fixed effects. ${ }^{16}$ Secondly, to mitigate the confounding effect from buy-side analysts, we include the number of buy-side analysts in the column (4) (Table 3 Panel B). Our results still hold. The coefficient of NUM_BUYSIDE (the number of buy-side analysts) is 0.069 (t stat 1.606), implying a positive relationship between number of sell-side analysts and number of buy-side analysts. It is unlikely that the observed reduction in sell-side coverage is driven by an increase in buy-side coverage.

\section{Conclusion}

As hedge fund activism has increasingly become a prominent phenomenon, it has substantially changed and shaken up public companies. Hedge funds, however, are end consumers of sell-side analyst research. Sell-side reports include much information about a given firm including valuation, prescriptions for maximizing shareholder value, and other objectives and tactics that hedge funds might use. We show that the activities of sell-side analysts are different for target firms before hedge fund activism occurs. The reduced coverage of sell-side analysts after hedge fund intervention is consistent with the view of substitute monitoring between sell-side analysts and buy-side institutions (Flugum and Souther 2018). In particular, sell-side analyst reports contain more terms related to subsequent activism and are correlated with activism outcomes (i.e. intervention date returns and multi-activist interventions). Through this analysis, we uncover a new, indirect monitoring mechanism for sell-side analysts in which they provide idea generation to activist hedge funds who can provide a stronger voice/“bark” that can be

\footnotetext{
16 The results are available in Appendix VII of the internet appendix.
} 
followed by action/“bite.” In short, sell-side analysts have negative voices that are in fact attributed to value creation by hedge fund activism.

Future studies should monitor any potential decline in sell-side research activities and its impact on hedge fund activism. For example, the introduction of MiFID has the potential to reduce resource allocation within investment banks to sell-side research. ${ }^{17}$ If sell-side analysts who generate activist ideas do not transition to other sell-side institutions or activist hedge funds themselves, the identification of activist targets may become more difficult and some firm shareholders may not realize the corporate governance benefits of hedge fund activism.

${ }^{17}$ See MiFID II Set to Disrupt Investment Research Worldwide, Bloomberg Intelligence https://www.bloomberg.com/professional/blog/mifid-ii-set-disrupt-investment-research-worldwide/ 


\section{References}

Admati, A. R., \& Pfleiderer, P. (2009). The "Wall Street Walk" and shareholder activism: Exit as a form of voice. Review of Financial Studies, 22(7), 2645-2685.

Agarwal, V., Daniel, N. D., \& Naik, N. Y. (2011). Do hedge funds manage their reported returns? Review of Financial Studies, 24(10), 3281-3320.

Asquith, P., Mikhail, M. B., \& Au, A. S. (2005). Information content of equity analyst reports. Journal of Financial Economics, 75(2), 245-282.

Bebchuk, L. A., Brav, A., \& Jiang, W. (2015). The Long-Term Effects of Hedge Funds Activism. Colum. L. Rev., 115, 1085.

Becht, M., Franks, J., Grant, J., \& Wagner, H. F. (2017). Returns to hedge fund activism: An international study. Review of Financial Studies, 30(9), 2933-2971.

Boyson, N. M., \& Pichler, P. (2016). Hostile resistance to hedge fund activism. Available at SSRN: https://ssrn.com/abstract=2805493

Brav, A., Heaton, J.B., \& Zandberg, J. (2016). Starboard Value and Wasau Paper (A). Duke University Case Study.

Brav, A., Jiang, W., \& Kim, H. (2010). Hedge fund activism: A review. Foundations and Trends® in Finance, 4(3), 185-246.

Brav, A., Jiang, W., \& Kim, H. (2015a). The real effects of hedge fund activism: Productivity, asset allocation, and labor outcomes. Review of Financial Studies, 28(10), 2723-2769.

Brav, A., Jiang, W., \& Kim, H. (2015b). Recent advances in research on hedge fund activism: Value creation and identification. Annual Review of Financial Economics, 7, 579-595.

Brav, A., Jiang, W., Ma, S., \& Tian, X. (2016). How does hedge fund activism reshape corporate innovation? (No. w22273). National Bureau of Economic Research.

Brav, A., Jiang, W., Partnoy, F., \& Thomas, R. (2008). Hedge fund activism, corporate governance, and firm performance. Journal of Finance, 63(4), 1729-1775.

Brav, A., \& Lehavy, R. (2003). An empirical analysis of analysts' target prices: Short-term informativeness and long-term dynamics. Journal of Finance, 58(5), 1933-1967.

Brown, L. D., Call, A. C., Clement, M. B., \& Sharp, N. Y. (2015). Inside the "black box" of sellside financial analysts. Journal of Accounting Research, 53(1), 1-47.

Brown, L. D., Call, A. C., Clement, M. B., \& Sharp, N. Y. (2016). The activities of buy-side analysts and the determinants of their stock recommendations. Journal of Accounting and Economics, 62(1), 139-156.

Call, A. C., Sharp, N. Y., \& Shohfi, T. D. (2018). Which Buy-Side Institutions Participate in Public Earnings Conference Calls? Implications for Capital Markets and Sell-Side Coverage. Working paper. Available at SSRN:

https://papers.ssrn.com/sol3/papers.cfm?abstract_id=2731930 
Chen, T., Harford, J., \& Lin, C. (2015). Do analysts matter for governance? Evidence from natural experiments. Journal of Financial Economics, 115(2), 383-410.

Cheng, Y., Liu, M. H., \& Qian, J. (2006). Buy-side analysts, sell-side analysts, and investment decisions of money managers. Journal of Financial and Quantitative Analysis, 41(1), 51-83.

Clifford, C. P. (2008). Value creation or destruction? Hedge funds as shareholder activists. Journal of Corporate Finance, 14(4), 323-336.

Flugum, R. and Souther, M. (2018). External Monitoring and Returns to Hedge Fund Activist Campaigns. Available at SSRN: https://ssrn.com/abstract=2823676

Huang, A. H., Lehavy, R., Zang, A. Y., \& Zheng, R. (2017). Analyst information discovery and interpretation roles: A topic modeling approach. Management Science.

Irvine, P., Lipson, M., \& Puckett, A. (2006). Tipping. Review of Financial Studies, 20(3), 741-768.

Greenwood, R., \& Schor, M. (2009). Investor activism and takeovers. Journal of Financial Economics, 92(3), 362-375.

Groysberg, B., Healy, P. M., \& Maber, D. A. (2011). What drives sell-side analyst compensation at high-status investment banks? Journal of Accounting Research, 49(4), 969-1000.

Griffin, J. M., \& Xu, J. (2009). How smart are the smart guys? A unique view from hedge fund stock holdings. Review of Financial Studies, 22(7), 2531-2570.

Gu, Z., Li, Z., \& Yang, Y. G. (2012). Monitors or predators: The influence of institutional investors on sell-side analysts. The Accounting Review, 88(1), 137-169.

Jung, M. J., Wong, M. F., \& Zhang, X. F. (2014). Analyst interest as an early indicator of firm fundamental changes and stock returns. The Accounting Review, 90(3), 1049-1078.

Kadan, O., Madureira, L., Wang, R., \& Zach, T. (2012). Analysts' industry expertise. Journal of Accounting and Economics, 54(2-3), 95-120.

Klein, A., Saunders, A., \& Wong, Y. T. F. (2017). Do hedge funds trade on private information? Evidence from upcoming changes in analysts' stock recommendations. Working Paper, New York University. Available at SSRN: https://ssrn.com/abstract=2421801

Klein, A., \& Zur, E. (2009). Entrepreneurial shareholder activism: Hedge funds and other private investors. Journal of Finance, 64(1), 187-229.

Lang, M., \& Lundholm, R. (1993). Cross-sectional determinants of analyst ratings of corporate disclosures. Journal of Accounting Research, 246-271.

Loughran, T., \& McDonald, B. (2011). When is a liability not a liability? Textual analysis, dictionaries, and 10-Ks. The Journal of Finance, 66(1), 35-65.

Mikhail, M. B., Walther, B. R., \& Willis, R. H. (1999). Does forecast accuracy matter to security analysts? The Accounting Review, 74(2), 185-200.

Mikhail, M. B., Walther, B. R., \& Willis, R. H. (2007). When security analysts talk, who listens? The Accounting Review, 82(5), 1227-1253. 
PwC, 10 Minutes on hedge fund activism - Strategies for staying out of activist cross hairs. (January 2016). http://www.pwc.com/us/en/10minutes/hedge-fund-activism.html\#section04

Swem, N. (2017). Information in financial markets: who gets it first? Working paper. Board of Governors of the Federal Reserve System. Available at SSRN:

https://papers.ssrn.com/sol3/papers.cfm?abstract_id=2437733

White, M.J. 2015. A Few Observations on Shareholders in 2015. Paper read at 27th Annual Corporate Law Institute, at Tulane University Law School. 


\section{Appendix A - Variable Descriptions}

\begin{tabular}{|c|c|}
\hline Dependent Variables & Description \\
\hline NUMEST & Number of analyst estimates from I/B/E/S. \\
\hline NUMREC & Number of analyst recommendations from I/B/E/S. \\
\hline NUM_ANALYST & Number of total analysts during a conference call. \\
\hline NUM_SELLSIDE & Number of sell-side analysts during a conference call. \\
\hline NUM_REPORT & Number of analyst reports issued for a given firm during a month. \\
\hline NUM_PAGE & Number of pages in analyst reports. \\
\hline NUM_WORD & Number of words in analyst reports. \\
\hline CAR $[-1,+1]$ & $\begin{array}{l}\text { Cumulative abnormal returns from } 1 \text { day before events to } 1 \text { day } \\
\text { after. }\end{array}$ \\
\hline MULTIACTIV & $\begin{array}{l}\text { An indicator variable that takes a value of } 1 \text { if more than one } \\
\text { activist is involved in hedge fund intervention, } 0 \text { otherwise. }\end{array}$ \\
\hline \multicolumn{2}{|l|}{ Independent Variables } \\
\hline DIC & $\begin{array}{l}\text { Activism dictionary percentage in analyst reports=number of } \\
\text { dictionary-related words/number of total words. }\end{array}$ \\
\hline DIC_HIGH & $\begin{array}{l}\text { An indicator variable that takes the value of one if monthly } \\
\text { dictionary coverage is above median of the sample, and zero } \\
\text { otherwise. }\end{array}$ \\
\hline POST & $\begin{array}{l}\text { An indicator variable that takes the value of one if year } t \text { is after a } \\
\text { firm being targeted by hedge fund activists, and zero otherwise. }\end{array}$ \\
\hline TREAT & $\begin{array}{l}\text { An indicator variable that takes the value of one if the firm has } \\
\text { been targeted during the sample period (treatment group), and zero } \\
\text { otherwise (control group). }\end{array}$ \\
\hline TREAT_POST & Interaction term of POST and TREAT. \\
\hline ROA & Return on total assets $=$ net income divided by total assets: NI/AT. \\
\hline SIZE & Firm size $=$ natural logarithm of total assets. \\
\hline LTDEBT & $\begin{array}{l}\text { Long-term debt is the ratio of long-term debt to the sum of debt } \\
\text { and market value of equity. }\end{array}$ \\
\hline BTM & Book to market ratio: $\mathrm{CEQ} /\left(\mathrm{PRCC} \_\mathrm{F}^{*} \mathrm{CSHO}\right)$. \\
\hline MISS & $\begin{array}{l}\text { An indicator variable that equals one if the actual EPS is less than } \\
\text { the last consensus EPS forecast, and zero otherwise. }\end{array}$ \\
\hline LNMV & Natural logarithm of market capitalization. \\
\hline \multicolumn{2}{|l|}{ Other Variables } \\
\hline D_TARGET & $\begin{array}{l}\text { An indicator variable that takes the value of one if the company is } \\
\text { targeted by the hedge fund activists, and zero otherwise. }\end{array}$ \\
\hline MV & Market capitalization: natural logarithm of PRCC_F*CSHO. \\
\hline Q & $\begin{array}{l}\text { Tobin's } Q=(\text { book value of debt }+ \text { market value of equity }) /(\text { book } \\
\text { value of debt }+ \text { book value of equity). }\end{array}$ \\
\hline GROWTH & $\begin{array}{l}\text { Growth rate of sales over the previous year: }\left(\mathrm{SALE}_{\mathrm{t}}-\mathrm{SALE}_{\mathrm{t}-1}\right) / \\
\text { SALE }_{\mathrm{t}-1} \text {. }\end{array}$ \\
\hline DIVYLD & $\begin{array}{l}\text { Dividend yield, defined as (common dividend }+ \text { preferred } \\
\text { dividends) / (market value of common stocks }+ \text { book value of } \\
\text { preferred). }\end{array}$ \\
\hline
\end{tabular}




\begin{tabular}{|l|l|}
\hline RND & R\&D scaled by total assets. \\
\hline HHI & $\begin{array}{l}\text { Herfindahl-Hirschman index of sales in different business } \\
\text { segments as reported by Compustat. }\end{array}$ \\
\hline ANALYST & The number of analysts covering the company from I/B/E/S. \\
\hline INST & $\begin{array}{l}\text { Target price divided by actual price. tp_p = medptg/prc. } \\
\text { medptg is analysts' median target price. prc is the stock price } \\
\text { TWO days before the target price announcement date. This } \\
\text { measure can be interpreted as the analyst's estimate of a firm's } \\
\text { annual expected return, which reflects the analyst's perception of a } \\
\text { firm's prospect. }\end{array}$ \\
\hline ESTP & $\begin{array}{l}\text { Estimated earnings divided by actual earnings. } \\
\text { est_act=meanest/actual. meanest is the average analysts' } \\
\text { forecasted annual earnings per share. actual is the actual earnings } \\
\text { per share that is announced after the end of the fiscal year. We do } \\
\text { not include quarterly estimated or actual earnings in the sample. } \\
\text { This ratio also reflects the analyst's perception of a firm's } \\
\text { prospect. }\end{array}$ \\
\hline Percentage of positive words in conference calls. \\
Percentage of negative words in conference calls.
\end{tabular}




\section{Appendix B - Activism Dictionary based on Brav et al. (2008)}

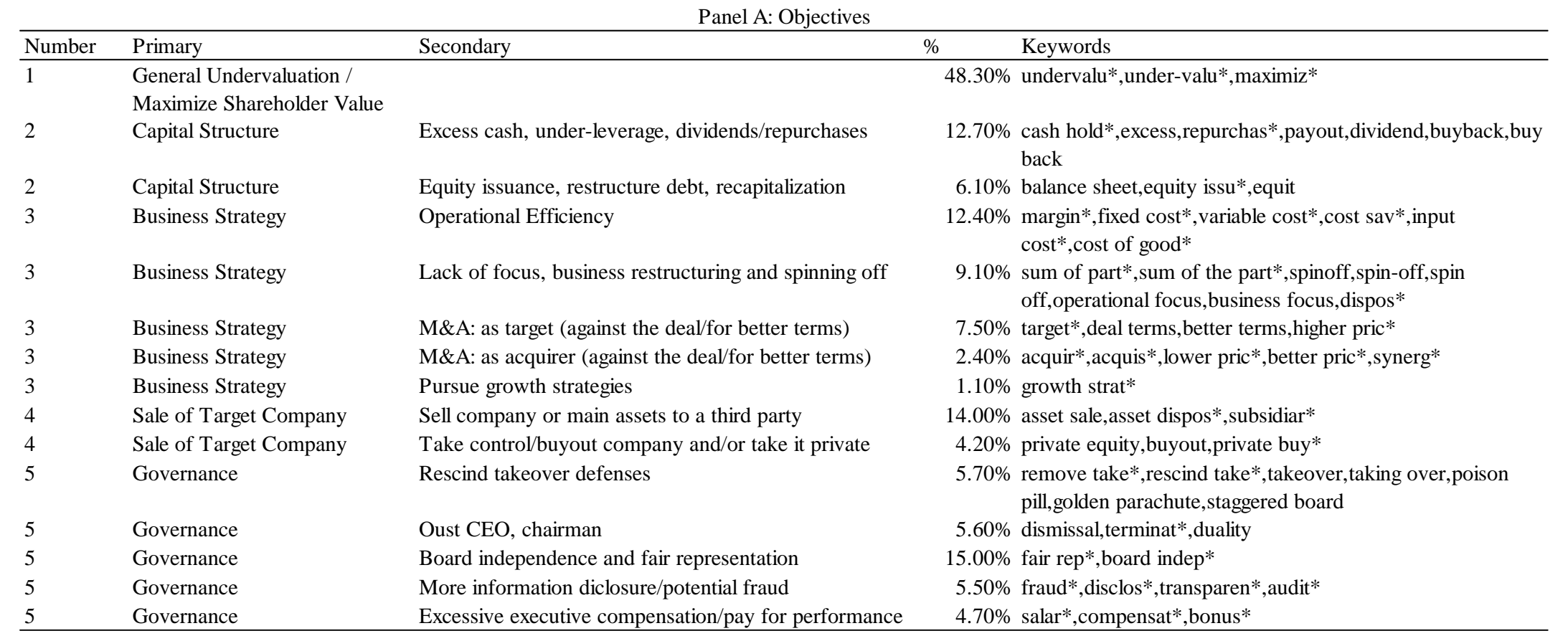

\begin{tabular}{|c|c|c|}
\hline \multicolumn{3}{|c|}{ Panel B: Tactics } \\
\hline Number & Primary & Keywords \\
\hline 1 & $\begin{array}{l}\text { The hedge fund intends to communicate with the board/management } \\
\text { on a regular basis with the goal of enhancing shareholder value }\end{array}$ & $48.30 \%$ letter \\
\hline 2 & $\begin{array}{l}\text { The hedge fund seeks board represntation without a proxy contest or } \\
\text { confrontation with the existing management/board }\end{array}$ & $11.60 \%$ board rep* \\
\hline 3 & $\begin{array}{l}\text { The hedge fund makes formal shareholder proposals, or publicly } \\
\text { criticizes the company and demands change }\end{array}$ & $32.00 \%$ propos* \\
\hline 4 & $\begin{array}{l}\text { The hedge fund threatens to wage a proxy fight in order to gain board } \\
\text { representation, or to sue the company for breach of fiduciary duty, etc. }\end{array}$ & $7.60 \%$ breach*,fiduci* \\
\hline 5 & The hedge fund launches a proxy contest in order to replace the board & $13.20 \%$ proxy \\
\hline 6 & The hedge fund sues the company & $5.40 \%$ litigation,lawsuit,lawsuit \\
\hline 7 & $\begin{array}{l}\text { The hedge fund intends to take control of the company, for example, } \\
\text { with a takeover bid }\end{array}$ & $4.20 \%$ takeover,take control \\
\hline
\end{tabular}


Figure 1 - Time Series of Analyst Estimates and Recommendations
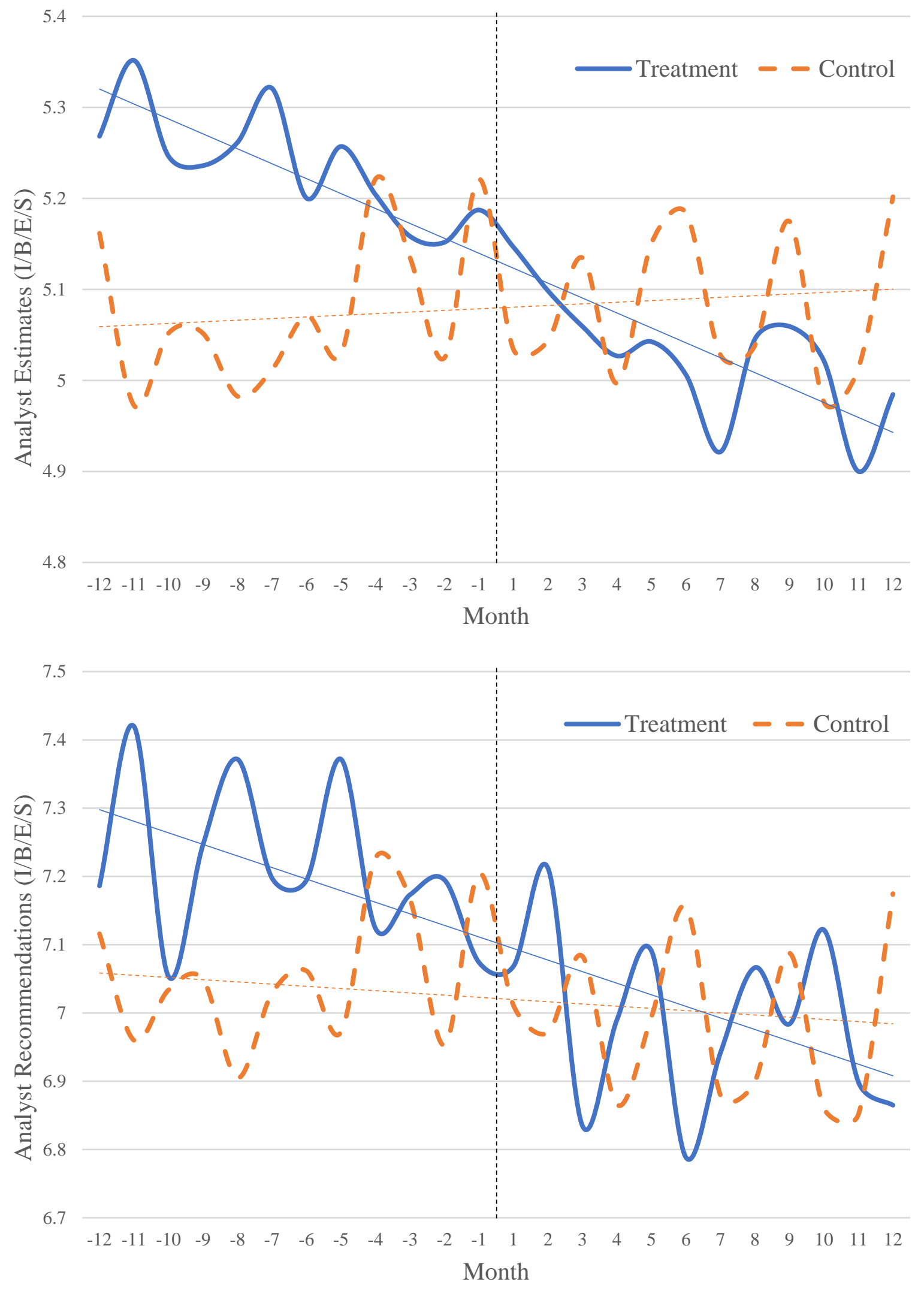
Figure 2 - Time Series of Analyst Reports and Analyst Conference Call Participation
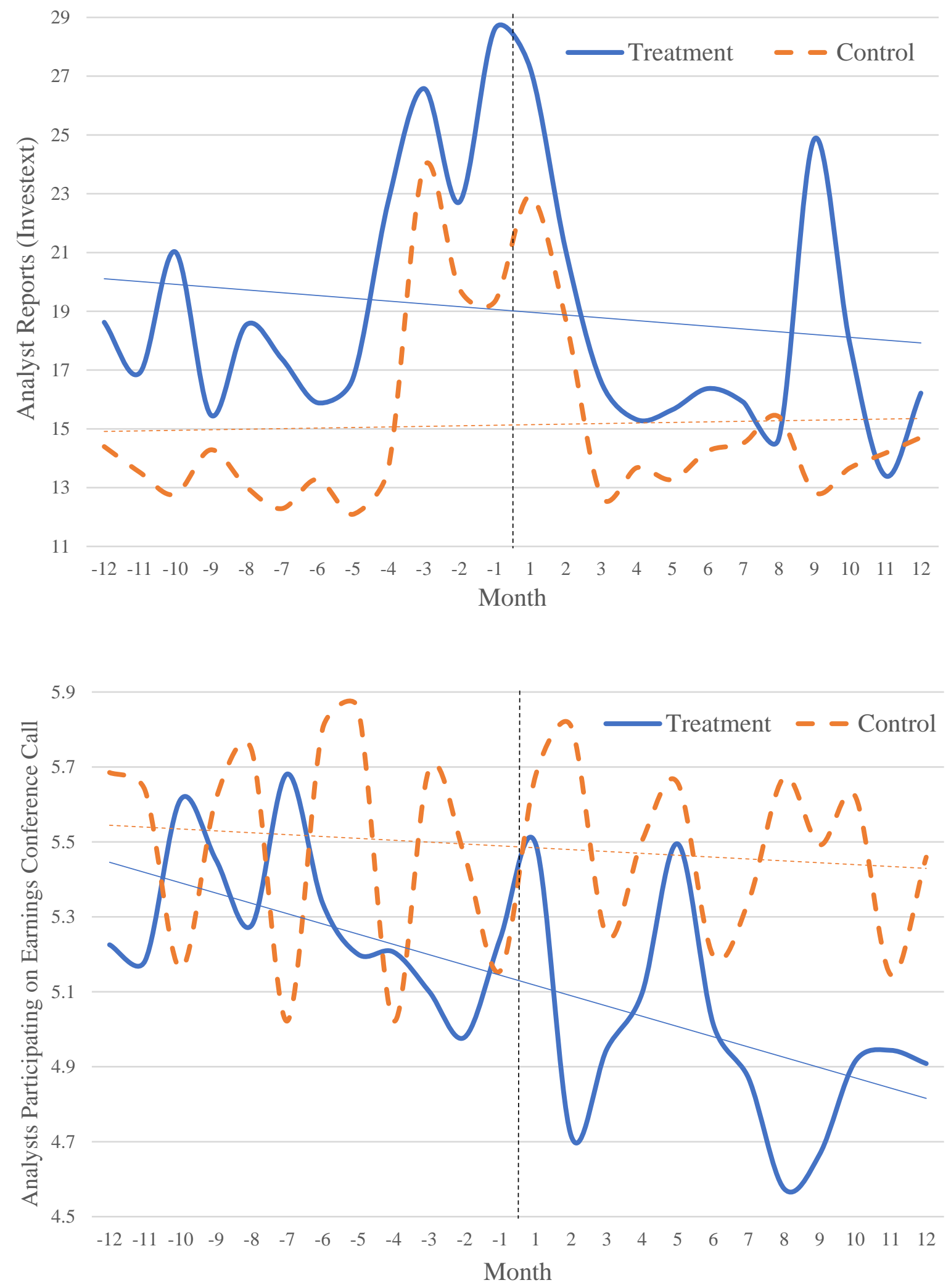
Figure 3 - Time Series of Activist Dictionary Words in Reports and Conference Calls
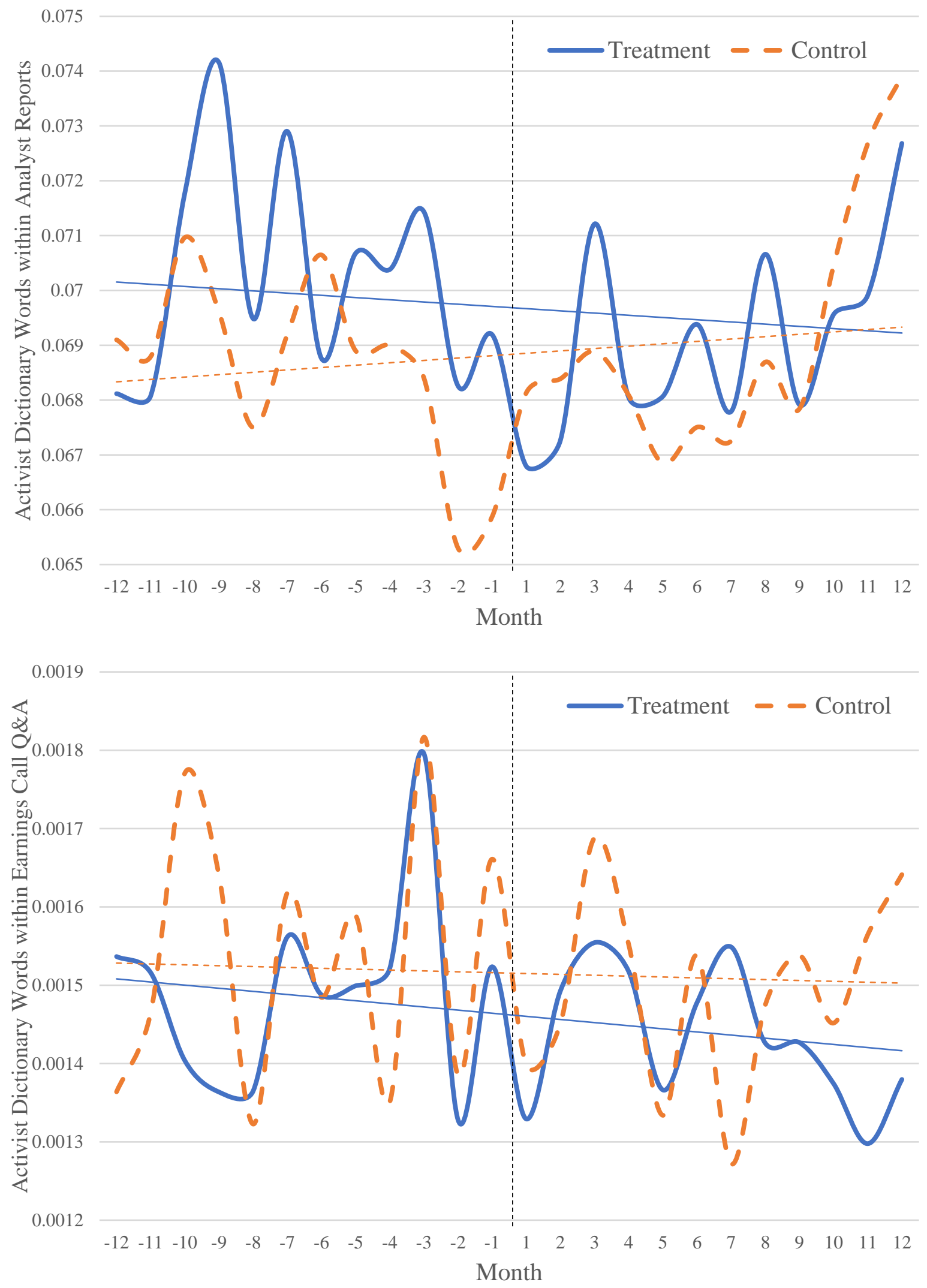
Table 1 - Sample and Summary Statistics

Panel A: Selection of Targeting Events

\begin{tabular}{|l|r|}
\hline & Number of events \\
\hline All targeting events from 2008 to 2017 & 4,669 \\
\hline Include only the first targeting event for each year & 1,800 \\
\hline Merge with Compustat data & 1,517 \\
\hline Merge with other datasets for target firms' characteristics & 1,286 \\
\hline After propensity score matching & 876 \\
\hline
\end{tabular}

Panel B: Summary Statistics

\begin{tabular}{|l|r|r|r|r|r|r|}
\hline & \multicolumn{1}{|c|}{ N } & \multicolumn{1}{|c|}{ MEAN } & \multicolumn{1}{c|}{ SD } & \multicolumn{1}{c|}{ P25 } & \multicolumn{1}{c|}{ P50 } & \multicolumn{1}{c|}{ P75 } \\
\hline NUMEST & 189702 & 5.068 & 5.090 & 2.000 & 3.000 & 7.000 \\
\hline NUMREC & 25584 & 6.975 & 6.193 & 3.000 & 5.000 & 9.000 \\
\hline NUM_ANALYST & 6022 & 5.260 & 3.412 & 3.000 & 5.000 & 7.000 \\
\hline NUM_SELLSIDE & 6022 & 4.063 & 3.237 & 2.000 & 3.000 & 6.000 \\
\hline NUM_REPORT $^{18}$ & 14893 & 1.892 & 2.012 & 1.000 & 2.000 & 2.000 \\
\hline NUM_PAGE $^{\text {NUM_WORD (in thousands) }}$ & 47782 & 9.126 & 7.873 & 5.000 & 7.000 & 10.000 \\
\hline NUM_ $^{19}$ & 14893 & 4.512 & 3.286 & 2.548 & 3.933 & 5.554 \\
\hline ROA & -0.032 & 0.213 & -0.044 & 0.023 & 0.059 \\
\hline SIZE & 14893 & 7.078 & 1.732 & 5.856 & 7.123 & 8.334 \\
\hline BTM & 14893 & 0.558 & 0.514 & 0.256 & 0.462 & 0.758 \\
\hline MISS & 14893 & 0.176 & 0.381 & 0.000 & 0.000 & 0.000 \\
\hline TP/P & 17427 & 2.285 & 5.725 & 1.073 & 1.215 & 1.455 \\
\hline EST/ACT & 21882 & 0.966 & 1.169 & 0.787 & 0.980 & 1.118 \\
\hline
\end{tabular}

${ }^{18}$ NUM_REPORT is the number of reports per day.

${ }^{19}$ We report the summary statistics of firm characteristics based on regression of NUM_REPORT. 


\section{Table 2 - Propensity Score Matching}

Panel A: Probit Analysis of Targeting

This panel reports the effects of covariates on the probability of being targeted by hedge fund activists. The dependent variable is an indicator variable equal to one if there is hedge fund activism targeting the company during the following year (that is, all covariates are lagged by 1 year). $* * *, * * *$ denote significance at the $10 \%, 5 \%$ and $1 \%$ levels (two-tailed), respectively. Detailed definitions of all variables are provided in the Appendix A.

\begin{tabular}{|c|c|}
\hline VARIABLES & D_TARGET \\
\hline MV & $\begin{array}{c}-0.000 * * * \\
(-7.883)\end{array}$ \\
\hline Q & $\begin{array}{c}-0.099 * * * \\
(-12.017)\end{array}$ \\
\hline GROWTH & $\begin{array}{c}-0.076 * * * \\
(-4.542)\end{array}$ \\
\hline ROA & $\begin{array}{c}0.067 * * \\
(2.207)\end{array}$ \\
\hline LEV & $\begin{array}{c}0.012^{* *} \\
(2.197)\end{array}$ \\
\hline DIVYLD & $\begin{array}{c}-1.219 * * * \\
(-4.390)\end{array}$ \\
\hline RND & $\begin{array}{c}0.498 * * * \\
(5.744)\end{array}$ \\
\hline HHI & $\begin{array}{c}-1.080 * * * \\
(-2.821)\end{array}$ \\
\hline ANALYST & $\begin{array}{c}0.012 * * * \\
(5.876)\end{array}$ \\
\hline INST & $\begin{array}{c}0.543 * * * \\
(16.304)\end{array}$ \\
\hline Constant & $\begin{array}{c}-1.796 * * * \\
(-90.699)\end{array}$ \\
\hline $\begin{array}{l}\text { Observations } \\
\text { Pseudo } \mathrm{R}^{2}\end{array}$ & $\begin{array}{l}66,198 \\
0.0487\end{array}$ \\
\hline
\end{tabular}




\section{Panel B: Differences between Treatment and Control Groups}

This panel reports the comparison of control variables between the treatment firms and the match firms. The treatment firms are firms that are targeted by the activist hedge funds. We use one-toone nearest neighbor propensity score match method. To ensure there are no significant differences between treatment firms and match firms, we use the caliper matching method and require a caliper of $3 \%$ during the match. The detailed definitions of all variables are provided in the Appendix A.

\begin{tabular}{lrrrrr}
\hline Variable & Treatment & Match & Difference & t Stat & $\mathrm{p}$ value \\
\hline & & & & & \\
MV & 1764.600 & 1964.300 & -199.700 & -0.880 & 0.377 \\
Q & 1.458 & 1.735 & $-0.277^{* *}$ & -2.120 & 0.034 \\
GROWTH & 0.113 & 0.107 & 0.006 & 0.280 & 0.783 \\
ROA & 0.038 & 0.015 & 0.023 & 1.550 & 0.122 \\
LEV & 1.396 & 1.490 & -0.094 & -1.260 & 0.209 \\
DIVYLD & 0.011 & 0.013 & $-0.002^{*}$ & -1.680 & 0.092 \\
RND & 0.067 & 0.071 & -0.004 & -0.730 & 0.463 \\
HHI & 0.009 & 0.008 & 0.001 & 1.090 & 0.277 \\
ANALYST & 5.045 & 4.830 & 0.215 & 0.890 & 0.374 \\
INST & 0.247 & 0.249 & -0.002 & -0.130 & 0.897 \\
\hline
\end{tabular}




\section{Table 3 - Changes in Analyst Coverage}

\section{Panel A: Univariate Difference-in-Difference (DID) Tests on Analyst Coverage}

This panel reports univariate DID tests of analyst coverage. NUMEST is the number of earnings estimates. NUMREC is the number of recommendations. NUM_ANALYST is the number of analysts participating conference calls. NUM_SELLSIDE is the number of sell-side analysts participating conference calls. $N U M_{-} R E P O R T$ is the aggregate number of analyst reports issued each month for a given firm. NUM_PAGE (NUM_WORD) is the number of pages (words, in thousands) in each report. A more detailed description of the variables is in Appendix A. The samples for NUMEST, NUMREC, NUM_SELLSIDE, and NUM_ANALYST are within twelve months before and after hedge fund intervention. The samples for NUM_REPORT, NUM_PAGE, and NUM_WORD are within three month ${ }^{20}$ (or one quarter) before and after hedge fund intervention.

\begin{tabular}{|c|c|c|c|c|c|c|}
\hline & \multicolumn{2}{|c|}{$\begin{array}{l}\text { Treatment Group } \\
\text { (Target Firms) }\end{array}$} & \multicolumn{2}{|c|}{$\begin{array}{l}\text { Control Group } \\
\text { (Matched Firms) }\end{array}$} & \multicolumn{2}{|c|}{$\begin{array}{l}\text { Cross-Sectional Mean } \\
\text { Difference }\end{array}$} \\
\hline Pre-Targeting & $\mathrm{N}$ (Firms) & Mean & $\mathrm{N}$ (Firms) & Mean & Difference & t-stat \\
\hline NUMEST & 642 & 5.228 & 558 & 5.159 & $0.070^{*}$ & 2.27 \\
\hline NUMREC & 642 & 5.228 & 558 & 5.159 & $0.070^{*}$ & 2.27 \\
\hline NUM_ANALYST & 562 & 5.568 & 444 & 5.460 & 0.108 & 0.94 \\
\hline NUM_SELLSIDE & 562 & 4.357 & 444 & 4.274 & 0.084 & 0.76 \\
\hline NUM_REPORT & 538 & 26.189 & 496 & 21.091 & $5.097 * * *$ & 18.630 \\
\hline NUM_PAGE & 538 & 8.723 & 496 & 9.156 & $-0.433 * * *$ & -8.040 \\
\hline NUM_WORD & 538 & 4.443 & 496 & 4.473 & -0.030 & -1.370 \\
\hline Post-Targeting & $\mathrm{N}$ (Firms) & Mean & $\mathrm{N}$ (Firms) & Mean & Difference & t-stat \\
\hline NUMEST & 647 & 5.038 & 551 & 5.171 & $-0.133 * * *$ & 4.27 \\
\hline NUMREC & 640 & 7.071 & 553 & 7.174 & -0.104 & 1.01 \\
\hline NUM_ANALYST & 534 & 5.185 & 443 & 5.500 & $-0.315^{* *}$ & -2.76 \\
\hline NUM_SELLSIDE & 534 & 4.049 & 443 & 4.309 & $-0.260 *$ & -2.42 \\
\hline NUM_REPORT & 547 & 22.500 & 503 & 18.838 & $3.662 * * *$ & 12.740 \\
\hline NUM_PAGE & 547 & 8.754 & 503 & 9.394 & $-0.640 * * *$ & -8.960 \\
\hline NUM_WORD & 547 & 4.386 & 503 & 4.530 & $-0.144 * * *$ & -5.510 \\
\hline Post-Pre & $\begin{array}{l}\text { Time-series } \\
\text { Estimator }\end{array}$ & t-stat & $\begin{array}{l}\text { Time-series } \\
\text { Estimator }\end{array}$ & t-stat & $\begin{array}{c}\text { DID } \\
\text { Estimator }\end{array}$ & t-stat \\
\hline NUMEST & $-0.190 * * *$ & -6.06 & 0.012 & 0.40 & $-0.202 * * *$ & -4.64 \\
\hline NUMREC & $-0.240^{*}$ & -2.30 & 0.069 & 0.70 & -0.172 & -1.19 \\
\hline NUM_ANALYST & $-0.383 * * *$ & -3.33 & -0.040 & -0.35 & $-0.423 * * *$ & -2.61 \\
\hline NUM_SELLSIDE & $-0.308 * *$ & -2.85 & -0.035 & -0.32 & $-0.344 * * *$ & -2.23 \\
\hline NUM_REPORT & $-3.688 * * *$ & -12.49 & $-2.253 * * *$ & -8.87 & $-1.435 * * *$ & -3.60 \\
\hline NUM_PAGE & 0.031 & 0.62 & $-0.238 * *$ & -3.16 & $-0.207 * *$ & -2.36 \\
\hline NUM_WORD & $-0.057 * *$ & -2.61 & $0.056^{*}$ & 2.15 & $-0.114 * * *$ & -3.35 \\
\hline
\end{tabular}

\footnotetext{
${ }^{20}$ We limit the sample of analyst reports to three months before or after hedge fund intervention due to the large
} number of analyst reports. 


\section{Panel B: Multivariate DID Regression on Analyst Coverage}

This panel reports results from DID OLS regressions. The dependent variables are measures of analyst coverage. POST is an indicator variable that takes the value of one if year $\mathrm{t}$ is after a firm being targeted by hedge fund activists, and zero otherwise. TREAT is an indicator variable that takes the value of one if the firm has been targeted during the sample period (treatment group), zero otherwise (control group). The variable of interest is the interaction term TREAT*POST. ROA is net income divided by total assets. SIZE is the natural logarithm of total assets. BTM is book to market ratio. MISS is an indicator variable that equals one if the actual EPS is less than the last consensus EPS forecast, and zero otherwise. A more detailed description of the variables is in Appendix A. The samples for NUMEST, NUMREC, NUM_SELLSIDE, and NUM_ANALYST are within twelve months before and after hedge fund intervention. The samples for NUM_REPORT, NUM_PAGE, and NUM_WORD are within three months (or one quarter) before and after hedge fund intervention. P-values are based on standard errors clustered at the firm level.

\begin{tabular}{|c|c|c|c|c|c|c|c|}
\hline VARIABLES & $\begin{array}{c}(1) \\
\text { NUMEST } \\
\end{array}$ & $\begin{array}{c}(2) \\
\text { NUMREC } \\
\end{array}$ & $\begin{array}{c}(3) \\
\text { NUM_ANALYST }\end{array}$ & $\begin{array}{c}(4) \\
\text { NUM_SELLSIDE }\end{array}$ & $\begin{array}{l}(5) \\
\text { NUM_REPORT }\end{array}$ & $\begin{array}{c}\text { (6) } \\
\text { NUM_PAGE } \\
\end{array}$ & $\begin{array}{c}(7) \\
\text { NUM_WORD }\end{array}$ \\
\hline TREAT & $\begin{array}{c}-0.298 \\
(-0.988)\end{array}$ & $\begin{array}{c}-1.287 * * \\
(-2.201)\end{array}$ & $\begin{array}{c}-0.155 \\
(-0.319)\end{array}$ & $\begin{array}{c}-0.031 \\
(-0.080)\end{array}$ & $\begin{array}{c}-0.005 \\
(-0.042)\end{array}$ & $\begin{array}{c}2.162 * * \\
(2.257)\end{array}$ & $\begin{array}{c}0.489 \\
(1.309)\end{array}$ \\
\hline POST & $\begin{array}{c}0.060 \\
(1.107)\end{array}$ & $\begin{array}{c}-0.001 \\
(-0.016)\end{array}$ & $\begin{array}{c}0.030 \\
(0.373)\end{array}$ & $\begin{array}{c}0.048 \\
(0.649)\end{array}$ & $\begin{array}{c}-0.024 \\
(-0.690)\end{array}$ & $\begin{array}{c}0.083 \\
(0.542)\end{array}$ & $\begin{array}{c}-0.019 \\
(-0.290)\end{array}$ \\
\hline TREAT*POST & $\begin{array}{c}-0.306 * * * \\
(-3.839)\end{array}$ & $\begin{array}{c}-0.390 * * * \\
(-3.617)\end{array}$ & $\begin{array}{c}-0.327 * * \\
(-2.565)\end{array}$ & $\begin{array}{c}-0.220 * * \\
(-1.968)\end{array}$ & $\begin{array}{l}-0.095^{*} \\
(-1.930)\end{array}$ & $\begin{array}{c}-0.325 \\
(-1.365)\end{array}$ & $\begin{array}{l}-0.147^{*} \\
(-1.735)\end{array}$ \\
\hline ROA & $\begin{array}{c}0.303 \\
(0.277)\end{array}$ & $\begin{array}{c}0.580 \\
(0.304)\end{array}$ & $\begin{array}{c}-0.095 \\
(-0.152)\end{array}$ & $\begin{array}{c}0.152 \\
(0.269)\end{array}$ & $\begin{array}{c}0.053 \\
(0.255)\end{array}$ & $\begin{array}{l}-2.613^{*} \\
(-1.670)\end{array}$ & $\begin{array}{c}-1.300 * * \\
(-2.133)\end{array}$ \\
\hline SIZE & $\begin{array}{l}1.357^{*} \\
(1.693)\end{array}$ & $\begin{array}{l}2.881 * \\
(1.781)\end{array}$ & $\begin{array}{c}0.194 \\
(0.386)\end{array}$ & $\begin{array}{c}0.474 \\
(1.226)\end{array}$ & $\begin{array}{c}0.347 * * * \\
(2.939)\end{array}$ & $\begin{array}{l}1.267 * \\
(1.719)\end{array}$ & $\begin{array}{c}0.770 * * * \\
(2.854)\end{array}$ \\
\hline BTM & $\begin{array}{c}-0.266 \\
(-1.026)\end{array}$ & $\begin{array}{c}-0.420 \\
(-1.040)\end{array}$ & $\begin{array}{c}-0.531 * * \\
(-2.357)\end{array}$ & $\begin{array}{l}-0.295^{*} \\
(-1.661)\end{array}$ & $\begin{array}{c}-0.075 \\
(-0.724)\end{array}$ & $\begin{array}{c}-0.407 \\
(-0.516)\end{array}$ & $\begin{array}{c}-0.060 \\
(-0.152)\end{array}$ \\
\hline MISS & $\begin{array}{c}0.016 \\
(0.465)\end{array}$ & $\begin{array}{c}0.040 \\
(0.859)\end{array}$ & $\begin{array}{c}0.082 \\
(0.939)\end{array}$ & $\begin{array}{c}0.040 \\
(0.559)\end{array}$ & $\begin{array}{c}0.016 \\
(0.284)\end{array}$ & $\begin{array}{c}-0.148 \\
(-0.785)\end{array}$ & $\begin{array}{c}0.089 \\
(1.395)\end{array}$ \\
\hline Constant & $\begin{array}{c}-3.497 \\
(-0.668)\end{array}$ & $\begin{array}{l}-10.595 \\
(-1.015)\end{array}$ & $\begin{array}{c}4.462 \\
(1.340)\end{array}$ & $\begin{array}{c}1.189 \\
(0.466)\end{array}$ & $\begin{array}{c}-0.483 \\
(-0.581)\end{array}$ & $\begin{array}{c}-1.359 \\
(-0.255)\end{array}$ & $\begin{array}{c}-1.519 \\
(-0.789)\end{array}$ \\
\hline Observations & 189,702 & 25,584 & 6,022 & 6,022 & 14,381 & 47,782 & 43,659 \\
\hline Adjusted $\mathrm{R}^{2}$ & 0.567 & 0.949 & 0.797 & 0.840 & 0.096 & 0.149 & 0.116 \\
\hline Firm Fixed Effects & YES & YES & YES & YES & YES & YES & YES \\
\hline
\end{tabular}




\section{Table 4 - Event Study on Analyst Reports and Analysis of Returns around Analyst Reports}

Panel A: Event Study on Analyst Reports and Univariate DID Test of Returns around Analyst Reports

This panel reports event study of issuance of sell-side analyst reports and univariate DID tests of cumulative abnormal return (CAR). We select analyst reports that are issued within five to ninety days before or after targeting event dates. To mitigate confounding effects, we exclude reports issued five days before or after targeting event dates and limit testing windows of CAR within five days. Both event study and CAR use value-weighted index and market model.

\begin{tabular}{|c|c|c|c|c|c|c|c|c|}
\hline & \multicolumn{3}{|c|}{$\begin{array}{l}\text { Treatment Group } \\
\text { (Target Firms) }\end{array}$} & \multicolumn{3}{|c|}{$\begin{array}{l}\text { Control Group } \\
\text { (Matched Firms) }\end{array}$} & \multicolumn{2}{|c|}{ Cross-Sectional Difference } \\
\hline \multicolumn{9}{|l|}{ Pre Targeting } \\
\hline Windows & $\mathrm{N}$ & CAR & Patell Z & $\mathrm{N}$ & CAR & Patell Z & Mean Difference & t-stat \\
\hline$(-5,+5)$ & 2940 & $-1.04 \% * * *$ & -4.45 & 2479 & $-0.40 \%$ & -1.46 & $-0.64 \% * *$ & -3.01 \\
\hline$(-2,+2)$ & 2940 & $-1.38 \% * * *$ & -7.64 & 2479 & $-0.35 \%$ & -0.14 & $-1.04 \% * * *$ & -5.80 \\
\hline$(-1,+1)$ & 2940 & $-1.33 \% * * *$ & -9.19 & 2479 & $-0.32 \%$ & 1.22 & $-1.01 \% * * *$ & -6.15 \\
\hline \multicolumn{9}{|l|}{ Post Targeting } \\
\hline$(-5,+5)$ & 3914 & $1.17 \% * * *$ & 7.29 & 3300 & $0.87 \% *$ & 1.70 & $0.30 \%$ & 1.57 \\
\hline$(-2,+2)$ & 3914 & $0.76 \% * * *$ & 6.32 & 3300 & $0.82 \% * * *$ & 3.21 & $-0.06 \%$ & -0.39 \\
\hline$(-1,+1)$ & 3914 & $0.73 \% * * *$ & 7.35 & 3300 & $0.79 \% * * *$ & 3.98 & $-0.07 \%$ & -0.48 \\
\hline \multicolumn{2}{|l|}{ Post - Pre } & $\begin{array}{c}\text { Time-series } \\
\text { Estimator }\end{array}$ & $\mathrm{t}$-stat & & $\begin{array}{c}\text { Time-series } \\
\text { Estimator }\end{array}$ & t-stat & DID Estimator & t-stat \\
\hline \multicolumn{2}{|l|}{$(-5,+5)$} & $2.21 \% * * *$ & 10.82 & & $1.27 \% * * *$ & 6.51 & $0.94 \% * * *$ & 3.27 \\
\hline \multicolumn{2}{|l|}{$(-2,+2)$} & $2.14 \% * * *$ & 12.48 & & $1.16 \% * * *$ & 7.34 & $0.98 \% * * *$ & 4.10 \\
\hline \multicolumn{2}{|l|}{$(-1,+1)$} & $2.06 \% * * *$ & -3.08 & & $1.12 \% * * *$ & 7.90 & $0.94 \% * * *$ & 4.34 \\
\hline
\end{tabular}


Panel B: Multivariate DID on Returns around Analyst Reports

This panel presents OLS regression of CAR around issuance of analyst reports within five to ninety days before (or after in Model (2)) targeting events. In both columns, the dependent variable CAR is computed from one day before issuance of analyst reports to one day after. In column (1), the variable of interest TREAT indicates whether it is in the control group or treatment group. In column (2), POST is an indicator variable that takes the value of one if year $t$ is after a firm being targeted by hedge fund activists, and zero otherwise. TREAT is defined the same as in column (1). The variable of interest is the interaction term TREAT*POST. ROA is net income divided by total assets. $L N M V$ is natural logarithm of market capitalization. $L T D E B T$ is the ratio of long-term debt to the sum of debt and market value of equity. BTM is book to market ratio. MISS is an indicator variable that equals one if the actual EPS is less than the last consensus EPS forecast, and zero otherwise. A more detailed description of the variables is in Appendix A. P-values are based on standard errors clustered at the firm level.

\begin{tabular}{lcc}
\hline \multirow{2}{*}{ VARIABLES } & $(1)$ & $(2)$ \\
TREAT & CAR $[-1,+1]$ & CAR [-1, +1] \\
POST & $-0.008 * * *$ & $-0.007 * *$ \\
& $(-2.950)$ & $(-2.579)$ \\
TREAT*POST & & 0.002 \\
& & $(0.877)$ \\
ROA & & $0.009 * *$ \\
& & $(2.344)$ \\
LNMV & -0.010 & -0.008 \\
& $(-1.107)$ & $(-1.292)$ \\
LTDEBT & 0.002 & $0.001 *$ \\
& $(1.405)$ & $(1.891)$ \\
BTM & 0.010 & 0.005 \\
& $(0.965)$ & $(0.960)$ \\
MISS & 0.004 & 0.001 \\
& $(0.936)$ & $(0.254)$ \\
Constant & -0.003 & -0.006 \\
& $(-0.535)$ & $(-1.484)$ \\
Observations & $-0.094 * * *$ & 0.011 \\
Adjusted R-squared & $(-8.200)$ & $(0.312)$ \\
Brokerage Firm Fixed Effects & & \\
\end{tabular}




\section{Table 5 - Univariate DID Tests of Dictionary Words in Analyst Reports}

This table reports univariate DID tests of activism dictionary. The variables of interest are the average percentage of activism dictionary words used in analyst reports issued within different time windows. For example, Pre-targeting DIC (one month) is the average percentage of activism dictionary words used in analyst reports issued one month before targeting events. The activism dictionary is based on the objectives and tactics of Brav, et al. (2008). A complete list of dictionary words is available in Appendix B.

\begin{tabular}{|c|c|c|c|c|c|c|}
\hline \multirow[b]{2}{*}{ Pre Targeting } & \multicolumn{2}{|c|}{$\begin{array}{l}\text { Treatment Group } \\
\text { (Target Firms) }\end{array}$} & \multicolumn{2}{|c|}{$\begin{array}{l}\text { Control Group } \\
\text { (Matched Firms) }\end{array}$} & \multicolumn{2}{|c|}{ Cross-Sectional Difference } \\
\hline & $\mathrm{N}$ & Mean & $\mathrm{N}$ & Mean & Mean Difference & t-stat \\
\hline DIC (one month) & 4531 & $6.929 \%$ & 3194 & $6.587 \%$ & $0.342 \% * *$ & 2.66 \\
\hline DIC (two months) & 8113 & $6.897 \%$ & 6252 & $6.559 \%$ & $0.338 \% * *$ & 3.63 \\
\hline DIC (three months) & 12104 & $6.981 \%$ & 9693 & $6.659 \%$ & $0.322 \% * * *$ & 4.18 \\
\hline DIC (six months) & 20083 & $7.005 \%$ & 16395 & $6.777 \%$ & $0.227 \% * * *$ & 3.80 \\
\hline DIC (nine months) & 27260 & $7.067 \%$ & 22725 & $6.804 \%$ & $0.263 \% * * *$ & 5.12 \\
\hline \multicolumn{7}{|l|}{ Post Targeting } \\
\hline DIC (one month) & 4110 & $6.689 \%$ & 3273 & $6.813 \%$ & $0.124 \%$ & 0.91 \\
\hline DIC (two months) & 6855 & $6.735 \%$ & 5970 & $6.825 \%$ & $0.090 \%$ & 0.89 \\
\hline DIC (three months) & 9455 & $6.844 \%$ & 8087 & $6.842 \%$ & $0.003 \%$ & 0.03 \\
\hline DIC (six months) & 16008 & $6.863 \%$ & 14418 & $6.800 \%$ & $0.062 \%$ & 0.95 \\
\hline DIC (nine months) & 22341 & $6.865 \%$ & 20776 & $6.798 \%$ & $0.067 \%$ & 1.22 \\
\hline Post-Pre & $\begin{array}{l}\text { Time-series } \\
\text { Estimator }\end{array}$ & t-stat & $\begin{array}{l}\text { Time-series } \\
\text { Estimator }\end{array}$ & t-stat & DID Estimator & t-stat \\
\hline DIC (one month) & $-0.240 \%$ & -1.96 & $0.226 \%$ & 1.60 & $-0.466 \% * *$ & -2.49 \\
\hline DIC (two months) & $-0.162 \%$ & -1.74 & $0.265 \% * *$ & 2.64 & $-0.427 \% * * *$ & -3.12 \\
\hline DIC (three months) & $-0.137 \%$ & -1.72 & $0.182 \% *$ & 2.18 & $-0.319 \% * * *$ & -2.75 \\
\hline DIC (six months) & $-0.142 \% *$ & -2.33 & $0.023 \%$ & 0.36 & $-0.165 \% *$ & -1.86 \\
\hline DIC (nine months) & $-0.202 \% * * *$ & -3.89 & $0.006 \%$ & 0.11 & $-0.208 \% * * *$ & -2.60 \\
\hline
\end{tabular}




\section{Table 6 - The Effect of Activism Dictionary on Hedge Fund Intervention Events}

\section{Panel A: Univariate Analysis}

This panel presents comparison of intervention-event CARs for target firms with high pre-event activism dictionary content in analyst reports and those with low dictionary content. We use the median dictionary words percentage $(4.822 \%)$ in three-month pre-intervention analyst reports as a cut-off point for high and low dictionary coverage firms.

\begin{tabular}{lcccc}
\hline \multicolumn{5}{c}{ Activism Date CARs } \\
\hline Windows & $\begin{array}{c}\text { High Dictionary } \\
\text { Content }\end{array}$ & $\begin{array}{c}\text { Low Dictionary } \\
\text { Content }\end{array}$ & Mean Difference & t stat \\
\hline$[-20,+20]$ & $5.929 \%$ & $4.697 \%$ & $1.230 \% * * *$ & 3.36 \\
{$[-10,+10]$} & $5.486 \%$ & $4.296 \%$ & $1.190 \% * * *$ & 4.95 \\
{$[-5,+5]$} & $5.735 \%$ & $5.085 \%$ & $0.650 \% * *$ & 3.23 \\
{$[-2,+2]$} & $3.943 \%$ & $3.484 \%$ & $0.459 \% * *$ & 3.23 \\
{$[-1,+1]$} & $4.032 \%$ & $3.341 \%$ & $0.691 \% * * *$ & 6.11 \\
\hline
\end{tabular}




\section{Panel B: Multivariate Analysis}

This panel presents OLS regression of intervention-event CARs on the intensity of activism dictionary words in pre-event analyst reports. Column (1) includes analyst reports issued nine months before activism events. The other columns are designed in a similar fashion. DIC_HIGH is an indicator variable that takes the value of one if monthly dictionary coverage is above median of the sample, and zero otherwise. ROA is net income divided by total assets. $L N M V$ is natural logarithm of market capitalization. LTDEBT is the ratio of long-term debt to the sum of debt and market value of equity. BTM is book to market ratio. MISS is an indicator variable that equals one if the actual EPS is less than the last consensus EPS forecast, and zero otherwise. A more detailed description of the variables is in Appendix A. P-values are based on standard errors clustered at the firm level.

\begin{tabular}{|c|c|c|c|}
\hline & $\begin{array}{c}\text { Nine months before } \\
\text { intervention }\end{array}$ & $\begin{array}{c}\text { Six months before } \\
\text { intervention }\end{array}$ & $\begin{array}{c}\text { Three months } \\
\text { before intervention }\end{array}$ \\
\hline VARIABLES & $\begin{array}{c}(1) \\
\text { CAR }[-1,+1] \\
\end{array}$ & $\begin{array}{c}(2) \\
\operatorname{CAR}[-1,+1] \\
\end{array}$ & $\begin{array}{c}(3) \\
\text { CAR }[-1,+1] \\
\end{array}$ \\
\hline DIC_HIGH & $\begin{array}{c}0.007 \\
(1.394)\end{array}$ & $\begin{array}{l}0.009 * \\
(1.719)\end{array}$ & $\begin{array}{c}0.011 * * \\
(2.033)\end{array}$ \\
\hline ROA & $\begin{array}{c}-0.027 \\
(-1.351)\end{array}$ & $\begin{array}{c}-0.029 \\
(-1.392)\end{array}$ & $\begin{array}{c}-0.034 \\
(-1.539)\end{array}$ \\
\hline LNMV & $\begin{array}{c}0.004 \\
(1.574)\end{array}$ & $\begin{array}{l}0.004^{*} \\
(1.667)\end{array}$ & $\begin{array}{c}0.005^{* *} \\
(2.026)\end{array}$ \\
\hline LTDEBT & $\begin{array}{c}-0.017 \\
(-0.973)\end{array}$ & $\begin{array}{c}-0.017 \\
(-0.957)\end{array}$ & $\begin{array}{c}-0.014 \\
(-0.764)\end{array}$ \\
\hline BTM & $\begin{array}{c}-0.000 \\
(-0.041)\end{array}$ & $\begin{array}{c}0.002 \\
(0.307)\end{array}$ & $\begin{array}{c}0.001 \\
(0.315)\end{array}$ \\
\hline MISS & $\begin{array}{c}-0.001 \\
(-0.148)\end{array}$ & $\begin{array}{c}-0.000 \\
(-0.004)\end{array}$ & $\begin{array}{c}-0.001 \\
(-0.079)\end{array}$ \\
\hline Constant & $\begin{array}{l}-0.038^{*} \\
(-1.923)\end{array}$ & $\begin{array}{l}-0.039^{* *} \\
(-2.002)\end{array}$ & $\begin{array}{c}0.037 \\
(1.632)\end{array}$ \\
\hline Observations & 16,910 & 11,548 & 6,002 \\
\hline Adjusted $\mathrm{R}^{2}$ & 0.063 & 0.067 & 0.082 \\
\hline Brokerage Firm Fixed Effects & YES & YES & YES \\
\hline
\end{tabular}




\section{Table 7 - The Effect of Activism Dictionary on Multiple Hedge Fund Activism}

This table presents logit regressions of intervention-events involving more than one activist on the intensity of activism dictionary words in pre-event analyst reports. Column (1) includes months of analyst reports issued nine months before activism events. The other columns are designed in a similar fashion. The dependent variable MULTIACTIV is an indicator variable that takes a value of one if more than one activist is involved in hedge fund intervention, and zero otherwise. The variable of interest $D I C \_H I G H$ is an indicator variable that takes the value of one if monthly dictionary coverage is above median of the sample, and zero otherwise. $R O A$ is net income divided by total assets. $L N M V$ is natural logarithm of market capitalization. $L T D E B T$ is the ratio of longterm debt to the sum of debt and market value of equity. BTM is book to market ratio. MISS is an indicator variable that equals one if the actual EPS is less than the last consensus EPS forecast, and zero otherwise. A more detailed description of the variables is in Appendix A. P-values are based on standard errors clustered at the firm level.

\begin{tabular}{|c|c|c|c|}
\hline & $\begin{array}{c}\text { Nine months } \\
\text { before intervention }\end{array}$ & $\begin{array}{l}\text { Six months before } \\
\text { intervention }\end{array}$ & $\begin{array}{c}\text { Three months } \\
\text { before intervention }\end{array}$ \\
\hline VARIABLES & $\begin{array}{c}\text { Logit } \\
(1) \\
\text { MULTIACTIV } \\
\end{array}$ & $\begin{array}{c}\text { Logit } \\
(2) \\
\text { MULTIACTIV } \\
\end{array}$ & $\begin{array}{c}\text { Logit } \\
(3) \\
\text { MULTIACTIV } \\
\end{array}$ \\
\hline DIC_HIGH & $\begin{array}{c}0.980 * * * \\
(3.712)\end{array}$ & $\begin{array}{c}1.244 * * * \\
(3.672)\end{array}$ & $\begin{array}{c}1.940 * * * \\
(3.149)\end{array}$ \\
\hline $\mathrm{ROA}$ & $\begin{array}{c}3.267 \\
(0.645)\end{array}$ & $\begin{array}{c}4.620 \\
(0.653)\end{array}$ & $\begin{array}{c}4.061 \\
(0.519)\end{array}$ \\
\hline SIZE & $\begin{array}{c}0.078 \\
(0.509)\end{array}$ & $\begin{array}{c}0.109 \\
(0.654)\end{array}$ & $\begin{array}{l}0.295^{*} \\
(1.712)\end{array}$ \\
\hline BTM & $\begin{array}{c}0.248 \\
(1.143)\end{array}$ & $\begin{array}{c}0.344 \\
(1.166)\end{array}$ & $\begin{array}{c}0.345 \\
(0.949)\end{array}$ \\
\hline MISS & $\begin{array}{c}-1.838 * * \\
(-2.055)\end{array}$ & $\begin{array}{c}-2.492 * * \\
(-2.533)\end{array}$ & $\begin{array}{c}-2.681 * * \\
(-2.051)\end{array}$ \\
\hline Constant & $\begin{array}{c}-8.402 * * * \\
(-4.031)\end{array}$ & $\begin{array}{c}-7.951 * * * \\
(-3.601)\end{array}$ & $\begin{array}{c}-8.944 * * * \\
(-3.868)\end{array}$ \\
\hline $\begin{array}{l}\text { Observations } \\
\text { Pseudo R } \\
\text { Year Fixed Effects } \\
\text { Brokerage Firm Fixed Effects }\end{array}$ & $\begin{array}{c}10,442 \\
0.1706 \\
\text { YES } \\
\text { YES }\end{array}$ & $\begin{array}{c}6,659 \\
0.1507 \\
\text { YES } \\
\text { YES }\end{array}$ & $\begin{array}{c}3,166 \\
0.1906 \\
\text { YES } \\
\text { YES }\end{array}$ \\
\hline
\end{tabular}




\section{Table 8 - Test of Communication between Hedge Funds and Sell-side Analysts}

Panel A: Test of Dictionary Words for Treatment Group by Geographical Distance

This table reports univariate DID tests of activism dictionary by geographical distance. The variables of interest are the average percentage of activism dictionary words used in analyst reports issued within different time windows. For example, Pre-targeting DIC (one month) is the average percentage of activism dictionary words used in analyst reports issued one month before targeting events. The activism dictionary is based on the objectives and tactics of Brav, et al. (2008). A complete list of dictionary words is available in Appendix B. We divide the treatment firms into two groups based on the geographical distance between hedge funds and brokerage firms. We use the zip code of headquarters to measure geographical distance. The subsample "Short Distance" consists of below-median distance, while the subsample "Long Distance" consists of abovemedian distance.

\begin{tabular}{|c|c|c|c|c|c|c|}
\hline \multirow{2}{*}{$\begin{array}{l}\begin{array}{l}\text { Treatment Group } \\
\text { (Target Firms) }\end{array} \\
\text { Pre Targeting } \\
\end{array}$} & \multicolumn{2}{|c|}{ Short Distance } & \multicolumn{2}{|c|}{ Long Distance } & \multirow[b]{2}{*}{ Mean Difference } & \multirow[b]{2}{*}{ t-stat } \\
\hline & $\mathrm{N}$ & Mean & $\mathrm{N}$ & Mean & & \\
\hline DIC (one month) & 1135 & $6.622 \%$ & 1163 & $6.944 \%$ & $-0.322 \%$ & -1.38 \\
\hline DIC (two months) & 1984 & $6.382 \%$ & 1984 & $6.944 \%$ & $-0.561 \% * *$ & -3.23 \\
\hline DIC (three months) & 2914 & $6.420 \%$ & 2916 & $6.988 \%$ & $-0.568 \% * * *$ & -3.91 \\
\hline DIC (six months) & 5550 & $6.440 \%$ & 5580 & $7.002 \%$ & $-0.563 \% * * *$ & -5.30 \\
\hline DIC (nine months) & 8223 & $6.537 \%$ & 8245 & $7.099 \%$ & $-0.562 \% * * *$ & -6.36 \\
\hline \multicolumn{7}{|l|}{ Post Targeting } \\
\hline DIC (one month) & 938 & $6.236 \%$ & 944 & $6.766 \%$ & $-0.354 \%$ & -1.52 \\
\hline DIC (two months) & 1770 & $6.184 \%$ & 1773 & $6.845 \%$ & $-0.524 \% * *$ & -3.01 \\
\hline DIC (three months) & 2747 & $6.427 \%$ & 2764 & $6.997 \%$ & $-0.554 \% * * *$ & -3.81 \\
\hline DIC (six months) & 5250 & $6.334 \%$ & 5279 & $6.967 \%$ & $-0.560 \% * * *$ & -5.28 \\
\hline DIC (nine months) & 7664 & $6.237 \%$ & 7665 & $6.941 \%$ & $-0.540 \% * * *$ & -6.11 \\
\hline Post-Pre & $\begin{array}{c}\text { Time-series } \\
\text { Estimator }\end{array}$ & t-stat & $\begin{array}{c}\text { Time-series } \\
\text { Estimator }\end{array}$ & t-stat & DID Estimator & t-stat \\
\hline DIC (one month) & $-0.386 \%$ & -1.62 & $-0.178 \%$ & -0.72 & $-0.208 \%$ & -0.61 \\
\hline DIC (two months) & $-0.198 \%$ & -1.16 & $-0.099 \%$ & -0.53 & $-0.099 \%$ & -0.40 \\
\hline DIC (three months) & $0.007 \%$ & 0.04 & $0.009 \%$ & 0.06 & $-0.002 \%$ & -0.01 \\
\hline DIC (six months) & $-0.106 \%$ & -1.03 & $-0.035 \%$ & -0.32 & $-0.071 \%$ & -0.47 \\
\hline DIC (nine months) & $-0.300 \% * * *$ & -3.51 & $-0.158 \%$ & -1.74 & $-0.142 \%$ & -1.14 \\
\hline
\end{tabular}




\section{Panel B: Test of Returns around Analyst Reports for Treatment Group by Geographical}

\section{Distance}

This panel presents OLS regression of CAR around issuance of analyst reports by Geographical Distance. In both columns, the sample includes analyst reports issued within five to ninety days before targeting events. In each column, we divide the sample into two groups based on the geographical distance between hedge funds and brokerage firms. We use the zip code of headquarters to measure geographical distance. The subsample in column (1) consists of belowmedian distance, while column (2) consists of above-median distance. The dependent variable $C A R$ is computed from one day before issuance of analyst reports to one day after. POST is an indicator variable that takes the value of one if year $t$ is after a firm being targeted by hedge fund activists, and zero otherwise. ROA is net income divided by total assets. $L N M V$ is natural logarithm of market capitalization. $L T D E B T$ is the ratio of long-term debt to the sum of debt and market value of equity. BTM is book to market ratio. MISS is an indicator variable that equals one if the actual EPS is less than the last consensus EPS forecast, and zero otherwise. A more detailed description of the variables is in Appendix A. P-values are based on standard errors clustered at the firm level.

\begin{tabular}{lcc}
\hline & Short Distance & Long Distance \\
\hline VARIABLES & $(1)$ & $(2)$ \\
POST & CAR [-1, +1] & CAR [-1, +1] \\
ROA & $0.027^{* * *}$ & $0.022^{* * *}$ \\
& $(3.309)$ & $(3.181)$ \\
LNMV & $-0.056^{* *}$ & 0.001 \\
& $(-2.257)$ & $(0.043)$ \\
LTDEBT & 0.002 & 0.002 \\
& $(0.957)$ & $(0.843)$ \\
BTM & 0.021 & -0.000 \\
& $(1.060)$ & $(-0.006)$ \\
MISS & $-0.010 *$ & $0.021 *$ \\
& $(-1.734)$ & $(1.705)$ \\
Constant & $-0.017 * *$ & $(-3.322)$ \\
& $(-2.290)$ & $0.043 *$ \\
Observations & 0.048 & $(1.863)$ \\
R-squared & $(1.171)$ & 4,441 \\
Brokerage Firm Fixed Effect & & 0.056 \\
\hline
\end{tabular}

